\title{
Phytoplankton and nutrients in the Helgoland region*
}

\author{
Max Gillbricht \\ Biologische Anstalt Helgoland (Zentrale); Notkestr. 31, D-2000 Hamburg 52, \\ Federal Republic of Germany
}

\begin{abstract}
During recent decades, phytoplankton stock on the one hand and inorganic nutrients ( $P$ and bound $N$ ) on the other have increased considerably in the southern North Sea, as demonstrated at a permanent station (since 1962) near the island Helgoland. This correlation between. phytoplankton and inorganic $\mathrm{P}$ and $\mathrm{N}$ need not have anything to do with causality; exceptional algal blooms have been observed and reported in the literature since in the $19^{\text {th }}$ century. Furthermore, these increases (four-fold for phytoplankton and two-fold for nutrients) are in the same range as the fluctuations from year to year under different hydrographical conditions. A detailed investigation carried out in 1981 demonstrated the presence of a slowly growing phytoplankton population. Starting with a considerable stock of flagellates in spring, it reached a peak in cell numbers over a long reproduction period which contrasted with the normal duration of a spring bloom of diatoms. These processes were not related to a limited production by $\mathrm{P}$ or $\mathrm{N}$. A considerable concentration of these nutrients was permanently available in the form of inorganic compounds. The total amount of nutrients surpassed by far the portion incorporated in the phytoplankton. This is a consequence of the fact that small organisms have a high metabolic rate. Therefore, the relation between stock and production (daily production $\approx$ stock) is completely different from that known e.g. in agriculture. The nutrients exist during the vegetation period mainly in the form of dissolved organic matter that is accessible to plankton. The great dynamics of this system, including a phase shifting during the year between inorganic $\mathrm{P}, \mathrm{N}, \mathrm{Si}$, and production, indicates the significance of permanent and fast. remineralization. Calculations demonstrate that the $\mathrm{n}$ a t u r al nutrient content of seawater normally satisfies the demands of phytoplankton present in the North Sea area under study. Only in the more productive coastal region (salinity $<30$ associated with fresh water run-offs of low nutrient content - an unrealistic assumption in the German Bight) might some limitation be observed. For diatoms, silicate may represent a critical component, but a high dynamic force exists in the presence of small Si concentrations. Therefore, a lack of silicon must not represent any limitation; however, knowledge on the silicon system is insufficient up to now.
\end{abstract}

\section{INTRODUCTION}

At the beginning of this century, some years after the first planktological publication by Hensen $(1887)$, Brandt $(1899,1902)$ started the discussion on the connection between nutrients and phytoplankton. He was highly influenced by Liebig's "law of the minimum" and especially impressed by the recently detected nitrogren cycle. On a geological time scale, the easily soluble nitrogen salts should have reached a critical concentration in the sea by now, but this state has not yet been observed. Brandt, on the contrary, assumed $\mathrm{N}$ to be growth-limiting as a consequence of denitrifying bacteria, as found by Baur (1902) in the Kiel Fjord. Many substances should have been enriched in

- Dedicated to Dr. Dr. h. c. Peter Kornmann on the occasion of his eightieth birthday. 
the sea over the time reaching concentrations dangerous for (normal) life. This situation cannot be observed. Therefore, processes must exist that hinder such increases by sedimentation (flocculation, precipitation, adsorption), by degassing or by chemical transformation, or maybe by means of specialized organisms. The sea is not in a state of permanency but, at the most, in one of dynamic equilibrium or even in one of continuous imbalance.

The consequence of these remarks by Brandt has not been considered in full up to now, and his ideas about the primacy of nutrients in phytoplankton development are still being discussed and are in good agreement with the findings by limnologists that a manmade input of $\mathrm{P}$ and/or $\mathrm{N}$ may add to the organic production enormously. There is, however, a fundamental difference in this respect between the situation in the sea and in freshwater. The phosphate content in the depths of the Atlantic Ocean $\left(50^{\circ} \mathrm{N}\right)$ is in the range of $1.3 \mu \mathrm{g}$ atom. $\mathrm{dm}^{-3}$ (Redfield et al., 1963) as the consequence of a long lasting input, whilst the natural content of total phosphorus in lakes may be much smaller, possibly only $0.1 \mu \mathrm{g}$ atom $\cdot \mathrm{dm}^{-3}$ (Chapra \& Robertson, 1977). However, the warm water sphere near the surface of the oceans located in lower latitudes is extremely impoverished with respect to nutrients. In the upwelling region off NW Africa the phytoplankton development may be initiated therefore by nutrient input as stated by Nathanson (1906), and is afterwards regulated by another component, possibly by vertical water movement (reduced sinking velocity) (Gillbricht, 1977).

One of the first problems met with when carrying out investigations on the subject of phytoplankton stock regulation by nutrients is that usually only the inorganic nutrients are determined or, to be quite exact, the substances that react with the respective reagents. Since the twenties of this century, it is known that organically bound nitrogen and phosphorus exist in solution. These substances were first detected in fresh water (Birge \& Juday, 1926; Juday \& Birge, 1931) and later on in the sea (cf. summary by Armstrong \& Harvey, 1950, for P). These authors concluded that most of the inorganic nutrients that disappear in springtime are not incorporated into organisms or detritus but are transformed into soluble organic substances, as demonstrated by Butler et al. (1979) for nitrogen. Accordingly, there is a great nutrient depot in the sea that is not normally detected. This situation, observed world-wide, has also been observed in the southern North Sea with respect to P (Kalle, 1937) and to N (Eberlein et al., 1985).

What is the origin of these great quantities of organic substances? Steiner (1938) demonstrated that up to $90 \%$ of the phosphorus in dead limnic plankton was transformed into phosphate by enzymatic processes within three days, associated with the important effect that phosphatase is released into the water reacting there with soluble organic phosphorus compounds. Hoffmann (1956) investigated marine plankton (diatoms, peridinians, copepods). After blocking the enzymes, $13 \%$ of the phosphorus was observed in the organisms as (inorganic) phosphate, whilst $40 \%$ of the organically bound phosphorus was in a soluble form. When the enzymes were not blocked, $29 \%$ of the organic $P$ was remineralized after $24 \mathrm{~h}$, and $77 \%$ of the rest of the organic $P$ from the copepods was dissolved in the water. These results demonstrate that dead organisms may not only be a continuous source of recently released inorganic nutrients but also of greater quantities of dissolved organic compounds.

The other possibility is that all this material is mainly a by-product of assimilation, as demonstrated by Braarud \& Føyn (1931) for the flagellates Carteria and Chlamydomonas, 
and measured directly by Fogg (1958) in lake waters with ${ }^{14} \mathrm{C}$ for blue-green algae. The mean value of the released substances is in the range of $5 \%$ of the production under optimal conditions (exponential growth phase) (Williams, 1975). This $5 \%$ is probably the main source of the dissolved organic material, which has its maximum $\mathrm{P}$ and $\mathrm{N}$ content during spring and summer (Table 1). All particulate nutrient compounds are only a small

Table 1. Distribution of nutrients in the English Channel and the Dutch coastal water. $S=$ summer (April to September); $\mathrm{W}=$ winter (October to March)

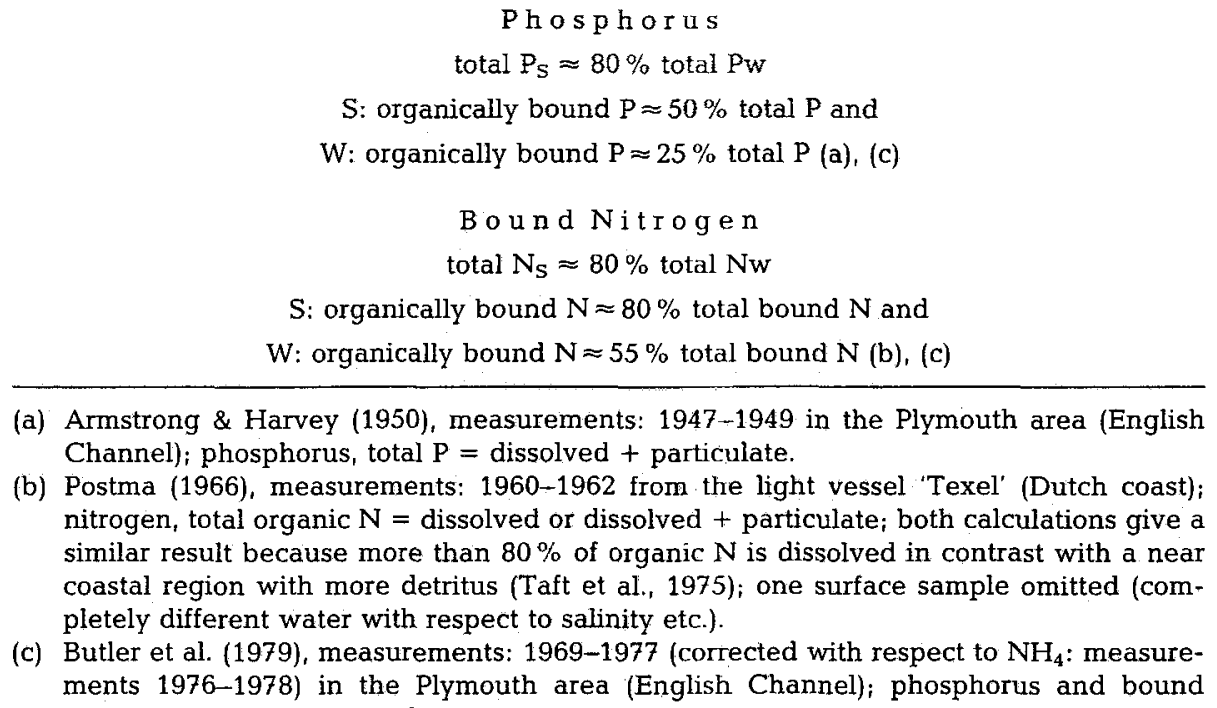

(a) Armstrong \& Harvey (1950), measurements: 1947-1949 in the Plymouth area (English

(b) Postma (1966), measurements: 1960-1962 from the light vessel 'Texel' (Dutch coast); nitrogen, total organic $\mathrm{N}=$ dissolved or dissolved + particulate; both calculations give a similar result because more than $80 \%$ of organic $\mathrm{N}$ is dissolved in contrast with a near coastal region with more detritus (Taft et al., 1975); one surface sample omitted (com-

(c) Butler et al. (1979), measurements: 1969-1977 (corrected with respect to $\mathrm{NH}_{4}$ : measurements 1976-1978) in the Plymouth area (English Channel); phosphorus and bound Channel); phosphorus, total $\mathrm{P}=$ dissolved + particulate. pletely different water with respect to salinity etc.). nitrogen, total $\mathrm{P}$ and $\mathrm{N}=$ dissolved.

fraction of the total stock, which has nearly the same quantity in summer as in winter. This does not contradict the assumption that the total short-cut nutrient cycle is mainly within the water column with an exchange between inorganically and organically bound dissolved $\mathrm{P}$ and $\mathrm{N}$ (p. 463). With regard to stratification according to density, nutrients may be distributed relatively homogeneously but with many organic compounds in the surface layer whilst $\mathrm{P}$ and $\mathrm{N}$ are remineralized near the bottom; by measuring the inorganic components, a situation is simulated that in fact does not exist (Armstrong \& Harvey, 1950; Butler et al., 1979). A completely different problem is whether the release of assimilation products depends on distinct species (Gillbricht, 1952,1983) as well as on the environmental conditions (Fogg, 1958).

All these facts indicate that there is a lot of different organic $\mathrm{P}$ and $\mathrm{N}$ compounds and a depot of inorganic nutrients. It is therefore possible to describe these inorganic components as mere intermediate products between the destruction of (mainly dissolved) organic substances by physico-chemical (UV), biological (bacteria, zooplankton), or any other processes on the one hand, and the assimilation of nutrients by phytoplankton (and also by bacteria and other organisms) on the other (Tarapchak \& Nalewajko, 1986). Therefore, the dynamics of the system cannot be seen directly, but only the relatively 
Table 2. Mean composition of marine organisms (atomic relations)

\begin{tabular}{lccccccccc}
\hline & $\mathrm{P}$ & $:$ & $\mathrm{N}$ & $:$ & $\mathrm{Si}$ & $:$ & $\mathrm{C}$ & \\
\hline 1 & $:$ & 19 & $:$ & 14 & $:$ & 107 & (a) \\
& 1 & $:$ & 16 & $:$ & - & $:$ & - & (b) \\
& 1 & $:$ & 15 & $:$ & - & $:$ & - & (c) \\
& 1 & $:$ & 16 & $:$ & - & $:$ & 106 & (d) \\
& 1 & $:$ & 16 & $:$ & 16 & $:$ & - & (e) \\
& 1 & $:$ & 14 & $:$ & 17 & $:$ & - & (f) \\
\cline { 2 - 7 } & 1 & $:$ & 16 & $:$ & 16 & $:$ & 106 & (g) \\
\hline
\end{tabular}

(a) Brandt \& Raben (1920), phytoplankton by net catches, Si: in the respective samples certainly not exclusively diatoms, therefore true relation possibly somewhat higher than 14.

(b) Schreiber (1927), misprints corrected, nutrient uptake by Carteria in culture.

(c) Braarud \& Føyn (1931), same method as Schreiber (1927) with Chlamydomonas.

(d) Fleming (1939), commonly used standard in good agreement with observations in sea (Gillbricht, 1977).

(e) Richards (1958), Si content of diatoms is difficult to determine (frustules as function of cell dimensions, mostly investigated bottom forms with thicker walls), plankton samples, no information about the obviously dominant diatom part, value for Si maybe slightly too low.

(f) Grill \& Richards (1964), remineralization during a tank experiment obviously influenced by bacteria; value for Si may be somewhat too high; calculated from nutrient changes between day 51 and day 93.

(g) Used in this investigation.

small fluctuations in the different compartments, and the inorganic release of $\mathrm{P}$ and also $\mathrm{N}$ takes place before the complete destruction of organic material occurs (Gillbricht, 1977). Therefore, an essential question is whether or not phytoplankton can use organically bound nutrients directly. This possibility was first described by Schreiber (1927) (uptake of glycin by Carteria), who established, however, that organically bound $\mathrm{P}$ cannot be assimilated directly. Both findings are still valid in the most cases discussed for urea (Verlencar, 1985) and amino acids (Flynn \& Butler, 1986). It is not known what proportion of this organic $\mathrm{N}$ source can be used directly by phytoplankton, possibly with different uptake velocities (Schell, 1974) and efficiencies for inorganic and organic components (Schreiber, 1927; Braarud \& Føyn, 1931). Organically bound P can be resorbed after hydrolysis by cell-surface alkaline phosphatase or other dissolved enzymes produced by phytoplankton, especially in the case of phosphate deficiency, and by micro-organisms (Stewart \& Wetzel, 1982; Tarapchak \& Nalewajko, 1986).

Minute nutrient concentrations allow an optimum growth rate of phytoplankton. Natural populations have an advantage in this respect over monocultures in laboratories (Tarapchak \& Nalewajko, 1986). Nutrient-deficient cells should not normally be observed in the sea. The results given by Sakshaug et al. (1983) may have been influenced by the statistics used (Gillbricht, 1974).

Discussions about nutrients and organisms need some information with respect to the composition of the latter. Examples given in literature for the atomic relations, including 


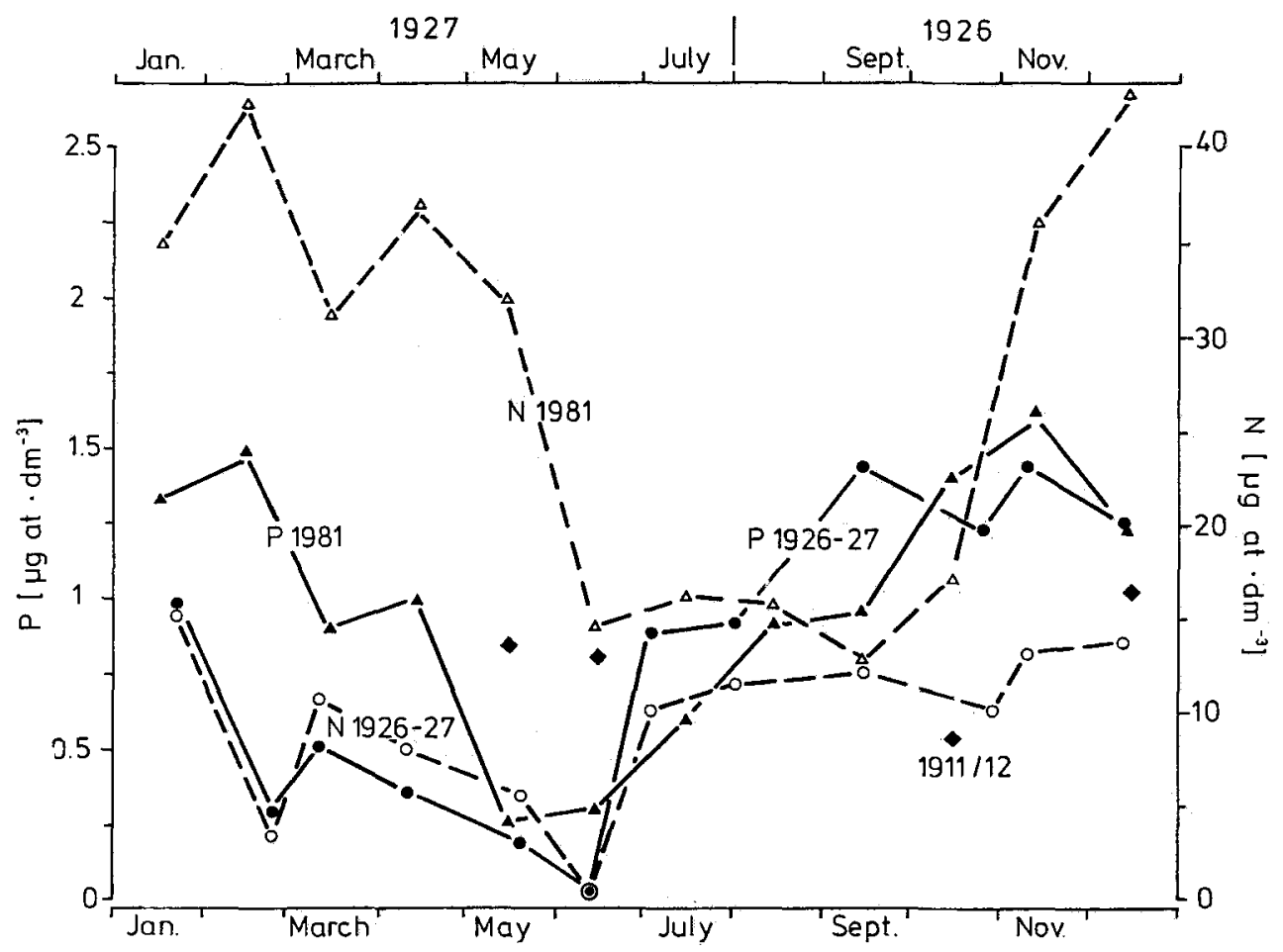

Fig. 1. Observations near Helgoland: after Raben in 1911/12 (N), after Schreiber in 1926/27 and the permanent station in 1981. $\mathrm{P}$ and $\mathrm{N}$ have the same scale with respect to the composition of organisms

Si in the case of diatoms, are summarized in Table 2. This outline indicates that the mean relations between the different elements allow rough estimates about the nutrient requirements of phytoplankton. The practical consequence of this fact is impressive in that it means that $1 \mu \mathrm{g}$ atom $\mathrm{P}$ is equivalent to $16 \mu \mathrm{g}$ atom $\mathrm{N}$ or Si (in diatoms) and to 1.3 mg C. In this way, the potential phytoplankton stocks can be calculated from observed nutrient concentrations in winter. The inorganic nutrient content in the waters near Helgoland (Fig. 1) is therefore much higher than is needed to build up the phytoplankton population during summer (Fig. 4).

A method described by Schreiber (1927) deserves special attention. The maximal cell number developing in a bacteria-free seawater sample with a monoculture of algae cells is determined directly and after adding a surplus of $\mathrm{P}$ or $\mathrm{N}$ to find out the concentrations and the "limiting" nutrient. Compared with chemical methods, this method is advantageous in that it measures exactly the quantities accessible for phytoplankton, or as Schreiber writes with respect to the nitrogen problem: "Die oben angeführte Lücke, daß die für das Plankton assimilierbaren N-Quellen bisher noch unbekannt sind, wird bei der neuen Methode dadurch überbrückt, daß bei der 'physiologischen' Stickstoffanalyse tatsächlich nur diejenigen $\mathrm{N}$-Verbindungen des Meerwassers angezeigt werden, die auch wirklich von der Algenzelle direkt assimiliert werden können." 
This, for a normal (chemical). laboratory, complicated method has never been used to a greater extent, but we must bear in mind that a monoculture cannot produce the species succession necessary for different and continually changing situations, and that the population investigated cannot permanently achieve an optimal adaptation. Additionally, observations made in a small vessel cannot or can with restrictions only be applied to the sea. Nevertheless, it would be of some interest to reproduce annual cycles (1926/27) using this method (single observations) and recent measurements (1981), and some $\mathrm{N}$ values by Raben (1914) from this region (Fig. 1). A comparison of the different results is difficult when one considers the different methods of determination and when the different hydrographical conditions are unknown. $\mathrm{P}$ and $\mathrm{N}$ have the same scale with respect to the (mean) composition of organisms. The $\mathrm{N}$ concentration may have increased during the last decades, whilst the situation is not so clear with respect to $\mathrm{P}$ (in this case in contrast to Fig. 2 and Weichart, 1986).

It is necessary to gain knowledge of the phytoplankton production not measured directly. The optimal daily increase of a diatom stock during a spring bloom is $\approx 15 \%$ (decrease $\approx 25 \%$ ), observed in a harbour basin (Gillbricht, 1955) and in the North Sea during FLEX '76. This is small compared with the production by natural marine populations, calculated as $140 \%$ from the data given by Thomas et al. (1978) and as more than $200 \%$ in culture experiments (Schöne, 1977; Baars, 1981). These values demonstrate the well known fact that small organisms have relatively high metabolic rates. In this way, a minute population with a minute nutrient content is the basis for high production in contrast to the situation with large plants in agriculture or forestry. In the range of $1 / 3$ of the gross production is respired over $24 \mathrm{~h}$, as can be deduced from the information given by Steemann Nielsen \& Hansen (1959). These findings indicate that a phytoplankton population has high permanent losses, and great decreases in production cause the stock to practically disappear from the water column within a short time. If there is any plankton in the sea, then its multiplication rate must be relatively constant.

This fact is used here for rough calculations assuming a daily production of diatoms of $100 \%$, in agreement with Krey (1953), as an integrated mean value of the euphotic zone. The production of other phytoplankton species (Thomas et al., 1978) - in the first range flagellates, preferably peridinians (Nordli, 1957; Elbrächter, 1977) - is about $50 \%$. This value is used considering that these organisms optimize their vertical distribution with respect to light (Gillbricht, 1983).

\section{MATERIAL AND METHODS}

Surface samples are taken on every working day around 9 a. m. on Helgoland Roads (German Bight; $54^{\circ} 11.3^{\prime} \mathrm{N}_{;} 7^{\circ} 54.0^{\prime} \mathrm{E}$ ) in a narrow passage between the island and the Dune. In the water, the following measurements are taken: temperature (thermometer), salinity (salinometer), phosphate, nitrate, nitrite, ammonium, silicate (Grasshoff, 1976), and phytoplankton by counting with the Utermöhl (inverted) microscope and by transformation into carbon by calculation (Hagmeier, 1961). This information is correct for the annual cycle 1981. During the long period of observation, some changes have been made with respect to the frequency of the measurements and methods used. These changes have had no practical consequences with respect to the problems discussed here.

The measurements were taken in water bodies that are permanently changing due to 


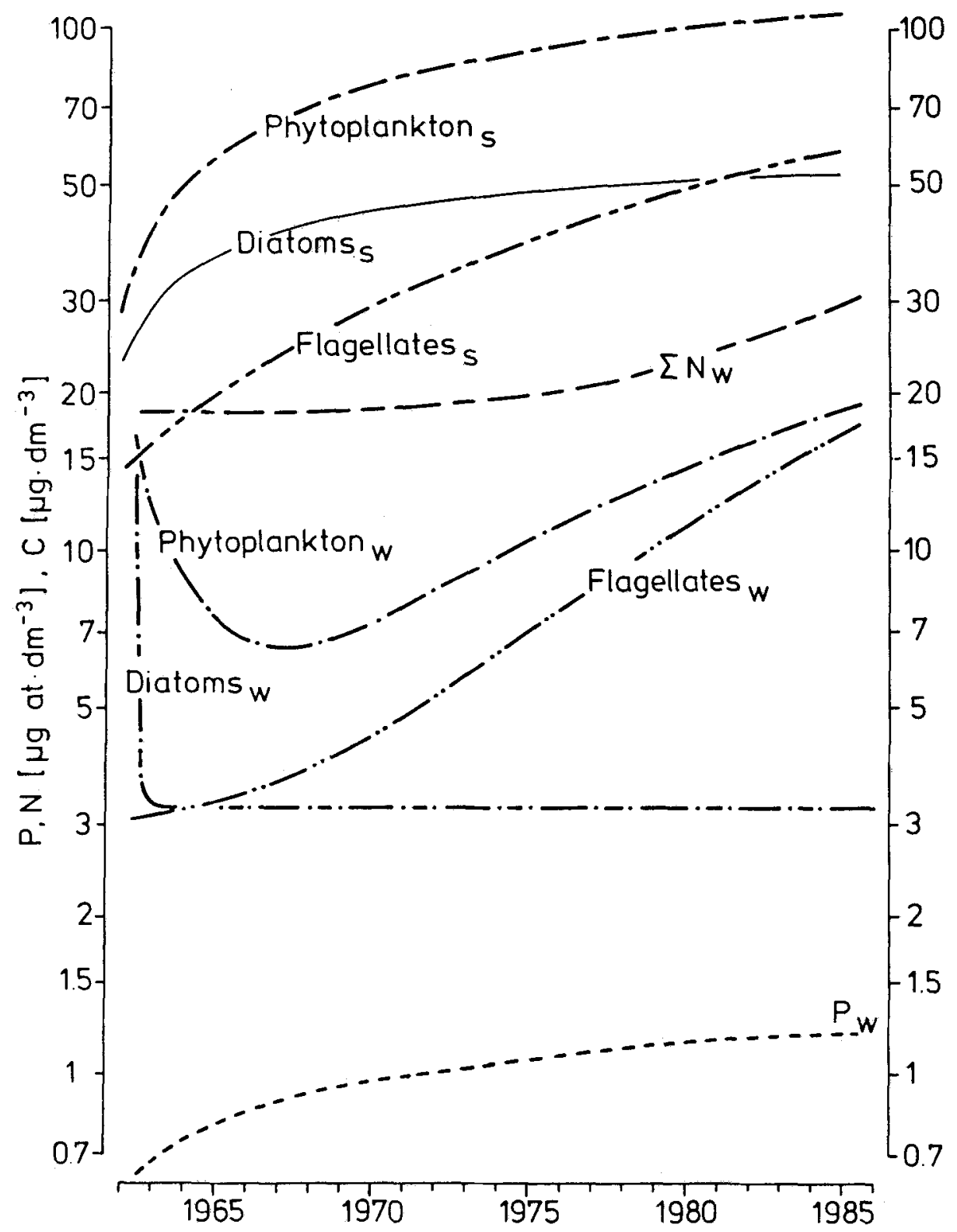

Fig. 2. Helgoland Roads 1962-1985: smoothed curves calculated from half-year means, $\mathrm{S}=$ summer (April to September), $W=$ winter (October to March). Phosphate $\left(\mathrm{P}_{\mathrm{w}}\right)$ and inorganic nitrogen $\left(\Sigma \mathrm{N}_{W}\right.$ $=\mathrm{NH}_{4}+\mathrm{NO}_{2}+\mathrm{NO}_{3}$ ) near the surface are given in $\left[\mu \mathrm{g}\right.$ at $\cdot \mathrm{dm}^{-3}$ l, phytoplankton (C) as $\left[\mu \mathrm{g} \cdot \mathrm{dm}^{-3}\right]$. The curve Diatoms $s_{S}$ is not significant; the ordinate has a logarithmic scale 


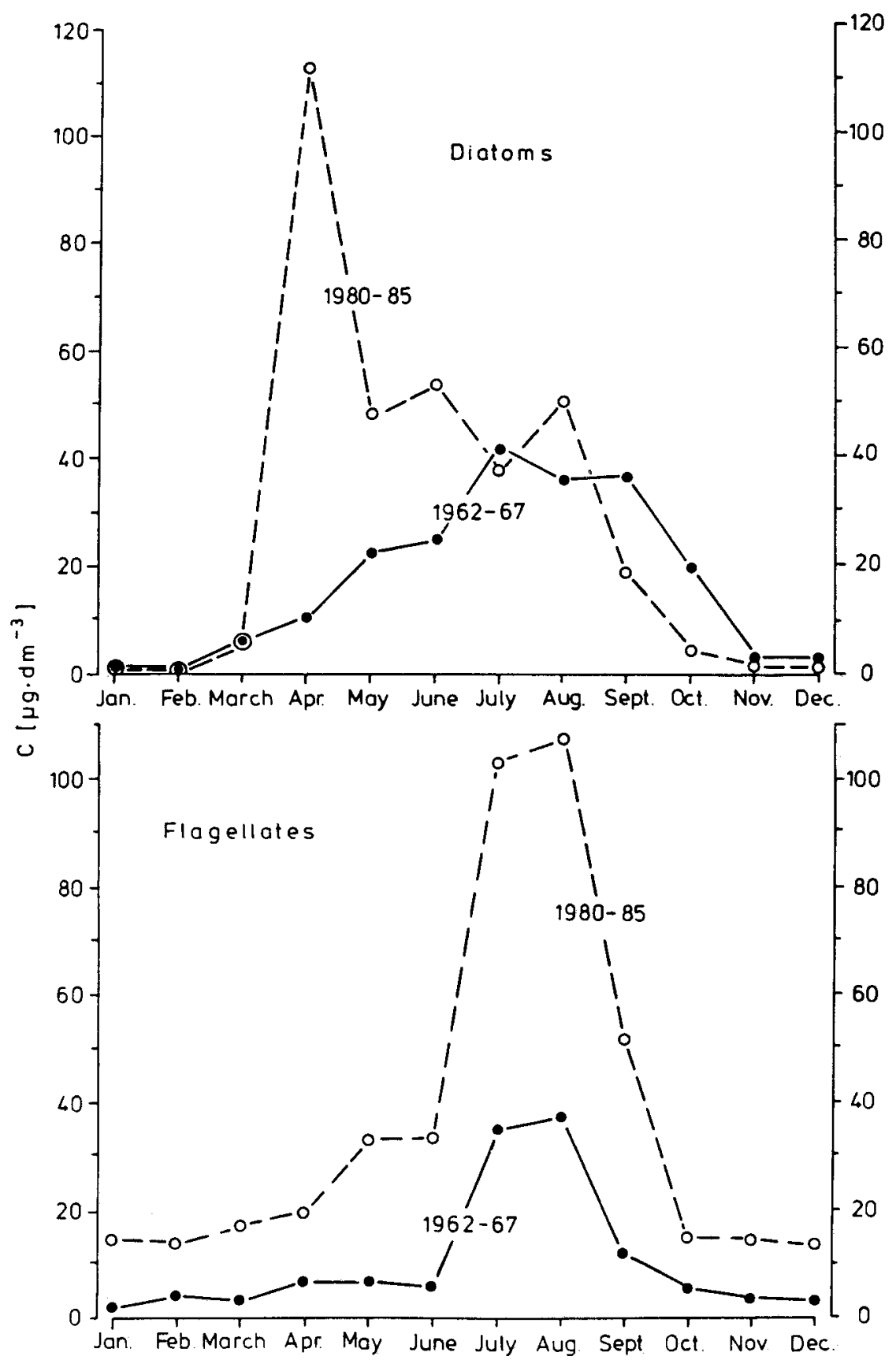

Fig. 3. Helgoland Roads: monthly means over six years (1962-67 and 1980-85) of diatoms and flagellates 


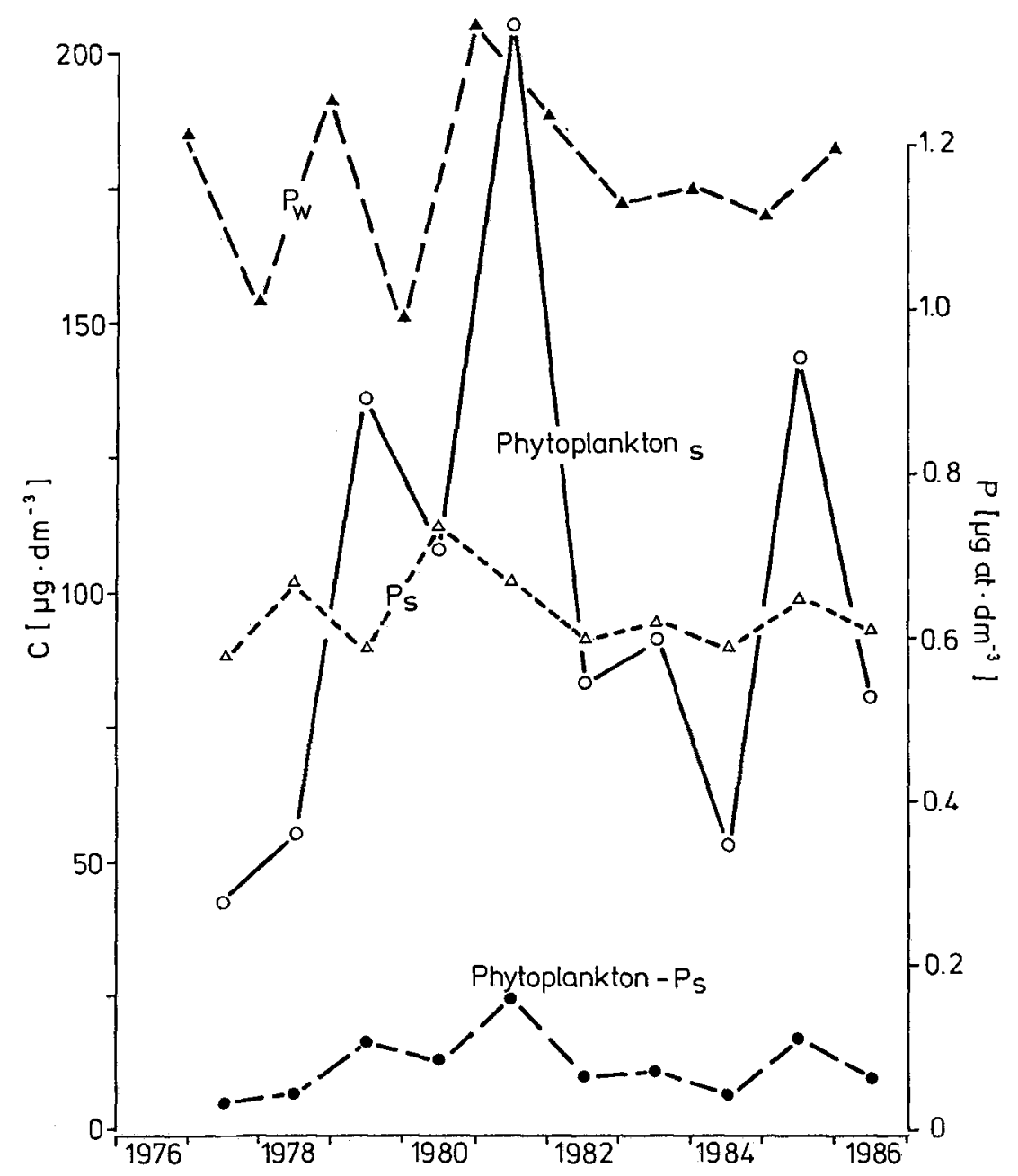

Fig. 4. Helgoland Roads 1976-1986: yearly means of phosphate $(P)$ in summer $=S$ (April to September) and in winter $=W$ (November to February), and of phytoplankton in summer, also given as its $\mathrm{P}$ content (Phytoplankton- $\mathrm{P}_{\mathrm{s}}$ )

periodic (tides), aperiodic (meteorology), and residual currents. It is therefore difficult to find out what biological events take place in a distinct water mass (Gillbricht, 1983). To overcome this problem as best one can, the results of the measurements are smoothed as functions of time and salinity. This method eliminates reasonably the effect of freshwater input by rivers, but it is not a good indicator of the mean coastal distance (different water depth and vertical turbulence), because salinity has an annual cycle that differs from year to year. The residual current parallel to the coast from $W$ to $E$ needs the assumption of the same conditions over a long distance to interpret our observations as true developments in time (Gillbricht, 1983). The following is an optimization of the equation ( $\mathrm{T}=$ time, $\mathrm{S}=$ salinity):

$$
y=a+b \cdot T^{c} \cdot S^{d}+e \cdot T^{f} \cdot S^{g}+\ldots
$$




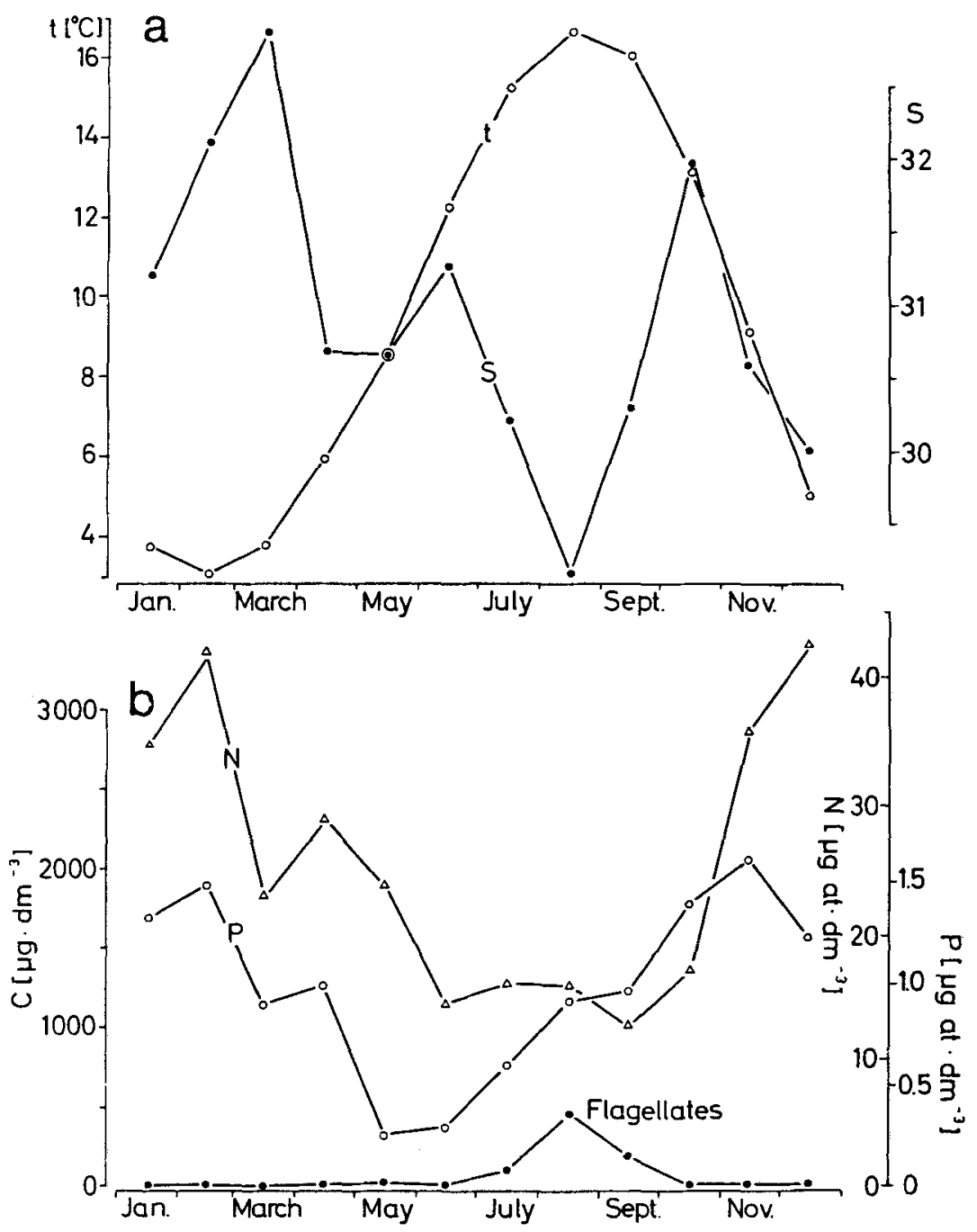

Fig. 5. Helgoland Roads 1981: monthly mean values. a: temperature (t) and salinity (S), b: phosphate $(\mathrm{P})$; inorganic nitrogen $(\mathrm{N})$ and flagellates. Scales are equal with respect to the mean composition of organisms

It is a polynomial function with (practically) error-free values on the right hand side as required by theory (Gillbricht, 1974). The solution of this equation in the case of known exponents by minimizing the sum of squares (observation - calculation) is well-known and not problematic. The optimization of the exponents must be done by approximation, and this is a difficult procedure. This formalistic method evades to a great extent pressing nature into a preconception. So as many terms (up to six) with $T$ and $S$ on the right hand side are used as are "significant" in a statistical sense $(\alpha<0.05)$, bearing in mind that this value is dubious under these conditions (no independence of the terms etc.). 


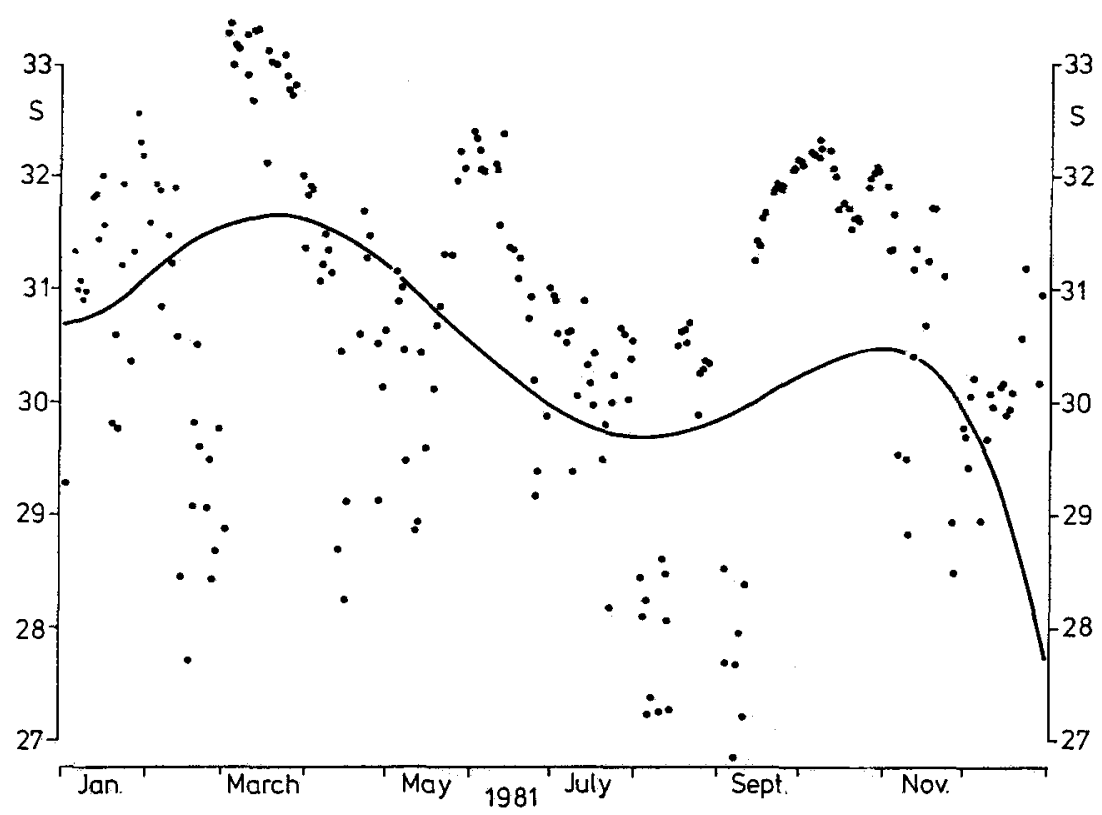

Fig. 6. Helgoland Roads 1981: salinity observations and calculated mean salinity as a function of time. $\mathrm{N}=$ number of observations $=244, \mathrm{R}=$ multiple correlation coefficient $=0.410, \alpha=$ probable error $<0.001$

In this respect, there is a special problem with the phytoplankton - diatoms and the rest (mainly flagellates [peridinians]). The quantities of these organisms vary exponentially in time and space (salinity). They can only be described reasonably in a logarithmic system which systematically gives smaller results than a numerical one, and they must be corrected before being compared with the nutrient situations. This is done by computing the logarithmic standard deviations of the observations from the calculated values in order to find the differences between the logarithmical and the respective numerical means. For this purpose, the two logarithmic plus and minus deviations are transformed into numerical values, and their mean may be something like the difference between the logarithmic and the numerical means that are to be found out. For diatoms and flagellates, a factor of about two has been determined, which has been used for the quantitative considerations. This method presents problems, but it may be better than directly comparing results found out by numerical and logarithmical smoothing. This fact is not exclusively disadvantageous. It indicates that the exponential gradients built up by biological processes are not destroyed to any extent by mixing, the elementary prerequisite for calculating true courses in a water body. Furthermore, the nutrient contents are not disturbed too much by the year cycles of the concentrations in the inflowing river water (ARGE Elbe, 1982).

\section{RESULTS}

The phytoplankton stock (especially the flagellates) and the concentrations of inorganic nutrients in winter time ( $\mathrm{P}$ and $\mathrm{N}$ ) increased continuously near Helgoland from 


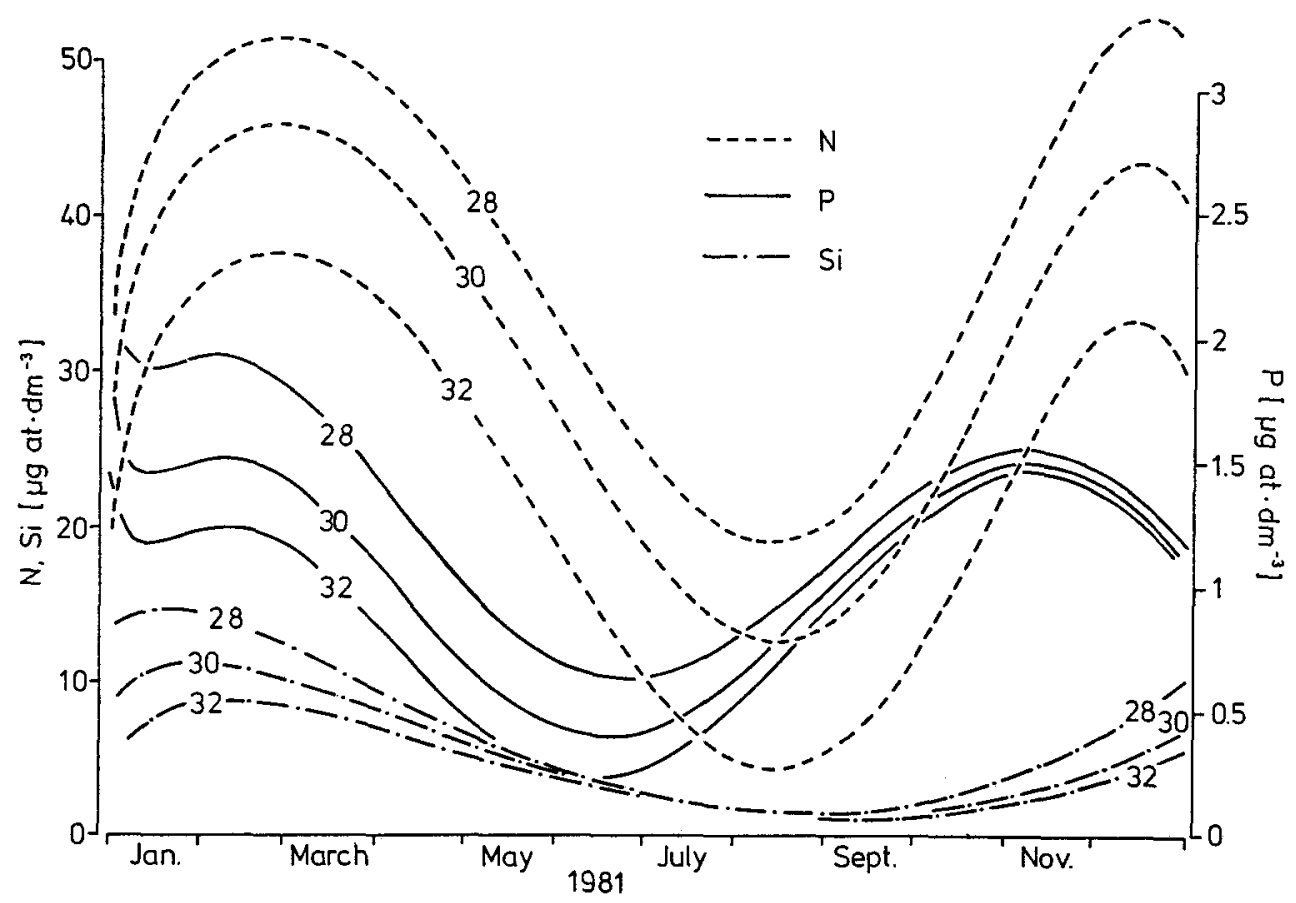

Fig. 7. Helgoland Roads 1981: smoothed annual cycles of the inorganically bound components of the nutrients $P, N$, and $\mathrm{Si}$ for the salinities 28,30 , and 32. Phosphate: $N=244, R=0.866, \alpha<<0.001$; nitrogen: $N=243, R=0.909, \alpha<<0.001$; silicate: $N^{\prime}=244, R=0.935, \alpha<<0.001$

1962 to 1985 . The respective smoothed curves are given in Figure 2. They are calculated from half-year means and presented (not calculated) in a logarithmic scale to find out whether or not changes in the quantities of different components are more or less proportional to one another. We must bear in mind, however, that good correlations may be purely formalistic and may have nothing to do with causality. This is especially the fact in the case of time series because a lot of components may change their quantities in one direction only, independent of each other over a long time span. This is a difficult problem from a theoretical point of view; in the main, negative results are reliable. We must keep this fact in mind when investigating exclusively the interrelations between nutrients and phytoplankton.

The measurements prove that phosphate in winter time $\left(\mathrm{P}_{\mathrm{w}}\right)$, the sum of the inorganic nitrogen compounds in winter time $\left(\Sigma N_{w}\right)$, the phytoplankton $(C)$ and its components without diatoms $\mathrm{s}_{\mathrm{w}}$ demonstrate something like parallelism (the phytoplankton stock increases four times and the concentrations of $\mathrm{P}$ and $\mathrm{N}$ twice) in so far as not to be completely contradictory to the assumption of a causality. But why does the flagellate (peridinian) stock, not fastidious with respect to nutrients (Gillbricht, 1983), increase not only in summer time but also in winter?

To gain better insight into the phytoplankton dynamics over the last two decades, monthly means taken over periods of six years are calculated. The four annual cycles 


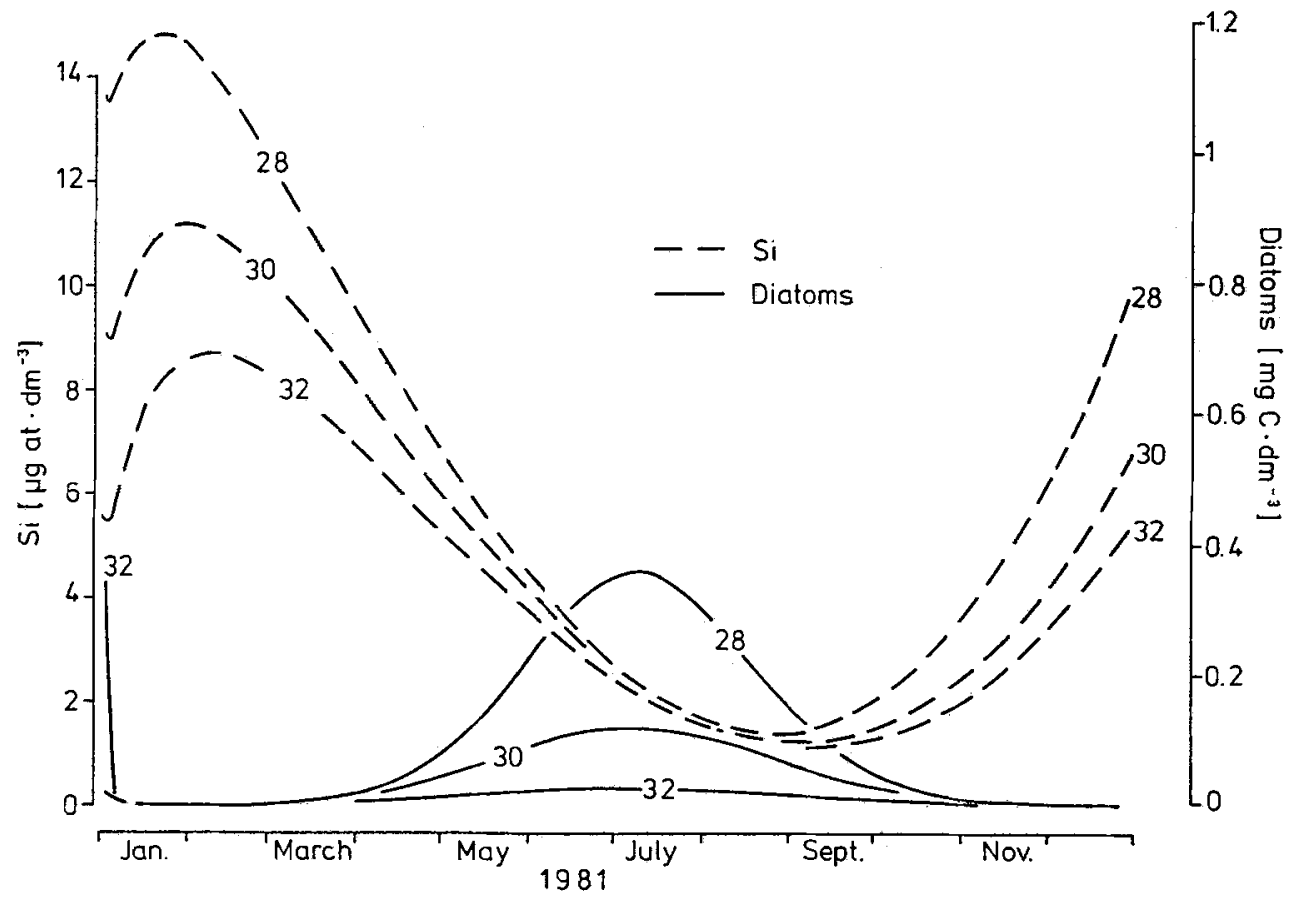

Fig. 8. Helgoland Roads 1981: smoothed annual cycles of silicate and diatoms for the salinities 28,30 , and 32

obtained in this way demonstrate a clear development during this time, as can be seen for the first and the last cycles in Figure 3. Whilst flagellates show a continuous increase during all seasons with a mass development of Ceratium in summer 1981, the situation is much more complicated with respect to diatoms. It is a well-known fact that the latter organisms produce a pronounced spring bloom. This was not observed during most of the investigation period. A maximum could be seen only in summer time, and the usual situation was (re-?)established during the last years with a spring bloom (Coscinodiscus) in 1985. These observations indicate that natural fluctuations in the sea may have very different time scales that cannot be completely detected during the life span of man or the duration of a permanent station. To find out more on this subject we turn to the literature where we find information from the $19^{\text {th }}$ century on phytoplankton blooms that were just as impressive as those observed today (cited by Steuer, 1910, and van Bennekom et al., 1975).

The fluctuations of phosphate in summer and winter, and of phytoplankton in summer, also given as incorporated $P$, demonstrate some interesting characteristics (Fig. 4). All the values scatter in a range like the increases during the long-term investigation (Fig. 2). Only a small proportion of the phosphate measured in winter can be observed in summer time in the plankton. Nevertheless, a reasonable quantity disappears from the water as usual, but the remaining amount indicates that there is always enough inorganic P available as not to limit phytoplankton development, as already 


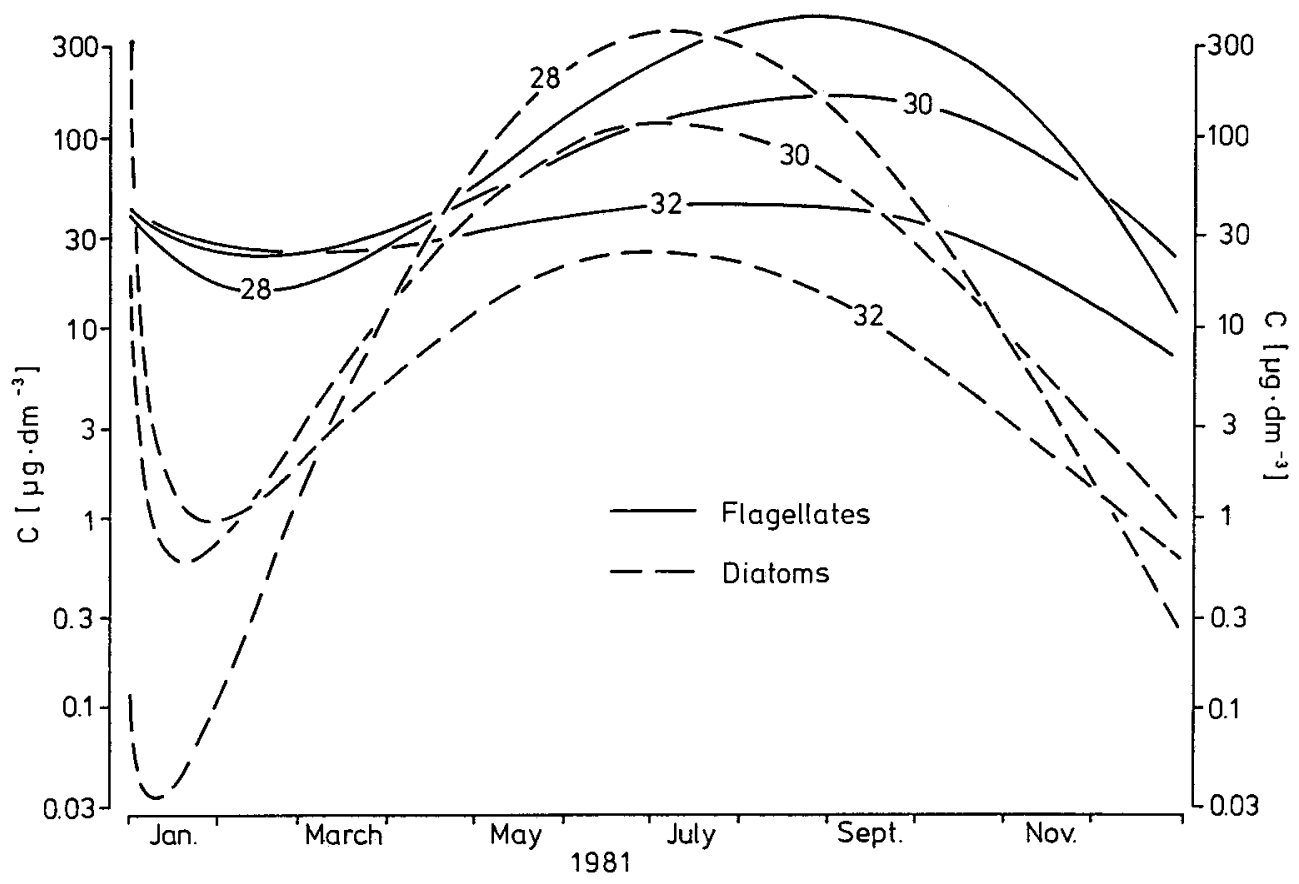

Fig. 9. Helgoland Roads 1981: smoothed annual cycles of diatoms and flagellates for the salinities 28, 30 , and 32. Values as $C$ (corrected) in a $\log$ scale; $\log$ (diatoms): $N=243, R=0.773, \alpha<<0.001$; $\log$ (flagellates): $\mathrm{N}=243, \mathrm{R}=0.815, \alpha<0.001$

proved for $\mathrm{P}$ and $\mathrm{N}$ in 1981 (Gillbricht, 1983). A slight parallelism between nutrient content and following phytoplankton stock may be seen; but we must bear in mind that $P$ is also an indicator of the hydrographic situation (salinity).

To investigate problems of this sort in detail it would be better to abandon long-term observations and to work with one single annual cycle only. For this purpose, the interesting year 1981 was selected with a strong Ceratium bloom that has already been examined exhaustively (Gillbricht, 1983) (Fig. 5). The scales in Figure $5 \mathrm{~b}$ are equal with respect to the (mean) composition of organisms, and the monthly means indicate the already known fact that the nutrient decrease in spring is high compared with the increase of the main phytoplankton component (flagellates) in that year. No nutrient limitation can be seen, and the regeneration of phosphate, difficult to understand regarding the short period of bloom in summer (Gillbricht, 1983) and practically not hindered by the Ceratium bloom, starts earlier in the year than the releasing of nitrogen components. We must assume therefore that the turnover of nutrients is enormous (shortcut regeneration and consumption) and cannot be seen by means of our measurements. The better regeneration of $\mathrm{P}$ compared with $\mathrm{N}$ may be the main reason for the smaller amplitude of $P$ over the year.

All these reflections are a little doubtful for the present, as can be seen in Figure 5a. Whilst the temperature curve is normal, the salinity demonstrates irregularities even using monthly means. This indicates considerable water exchange processes, which may 


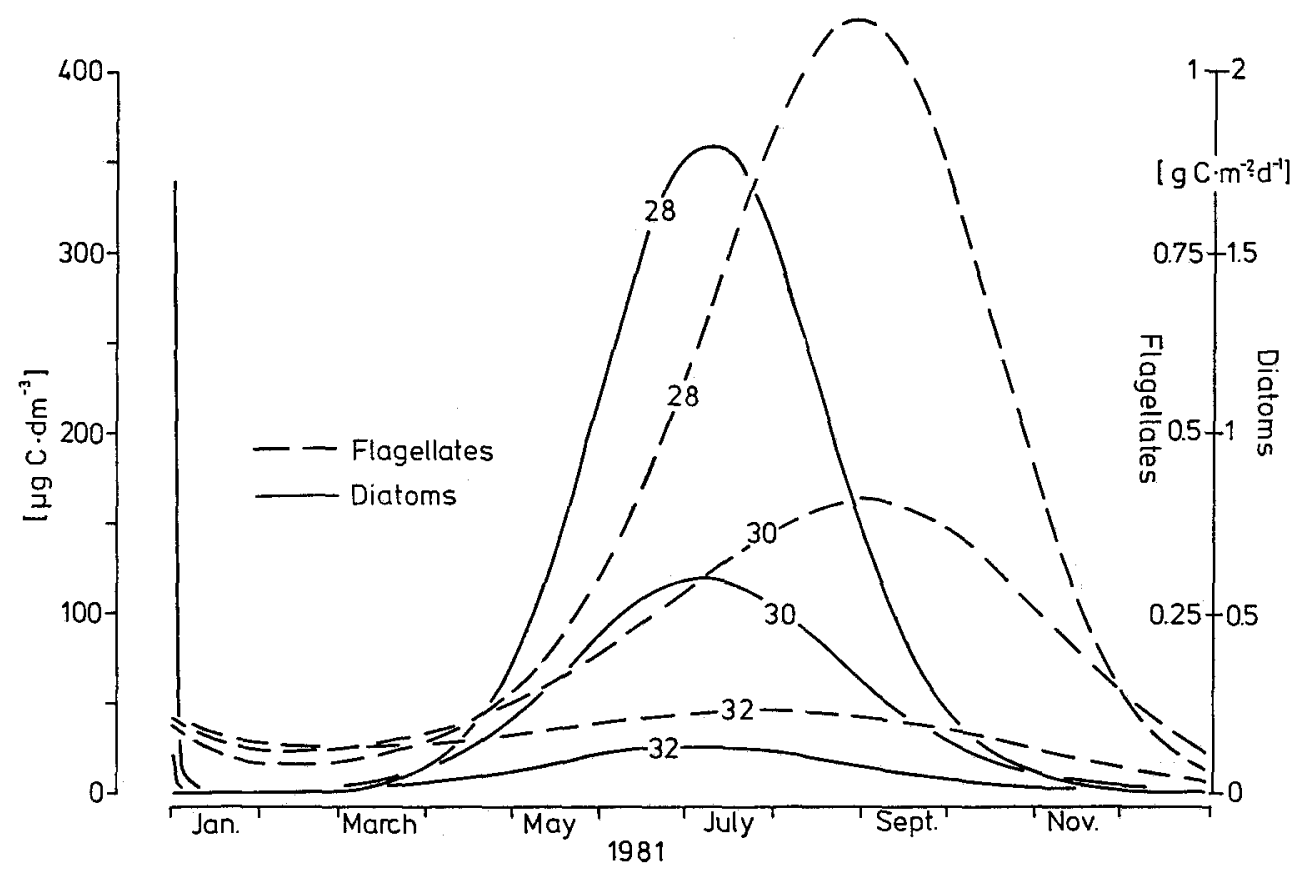

Fig. 10. Helgoland Roads 1981: smoothed annual cycles of diatoms and flagellates (stock and daily production of an euphotic zone of $5 \mathrm{~m}$ depth $\left.\left[\mathrm{g} \mathrm{C} \cdot \mathrm{m}^{-2} \cdot \mathrm{d}^{-1}\right]\right)$ for the salinities 28,30 , and 32 . Numerical scales

mask the purely biological run, the object of this investigation. Before starting with smoothing procedures as discussed already (p. 443), it is of interest to know something about the abnormally low salinity (Gillbricht, 1983) and its fluctuations during the year (Fig. 6). The single observations scatter in a wide range, and the impression is therefore that of an approximate and very abstract means curve with a dubious course in the boundary regions. It can be seen that a salinity range of 28 to 32 can be observed throughout the year. It is therefore possible to describe different annual cycles of nutrients and phytoplankton within this interval of salinity without extrapolating the observations. The respective curves are given in the following figures.

Under these conditions, the nutrients $\mathrm{P}$, especially $\mathrm{N}$, and, with limitations, Si show almost the same amplitudes independent of salinity in the observed range (Fig. 7). These findings are contradictory to the world-wide experience of larger plankton stocks in coastal regions (e.g. Gillbricht, 1959) under the assumption that there is a proportionality. between nutrients and phytoplankton. In this investigation, the scales are equal with respect to the mean composition of organisms, thus indicating that there is normally a surplus of $\mathrm{N}$ but with a phase difference in remineralization changed into a $\mathrm{P}$ surplus at least in the case of higher salinities. For diatoms, the low silicate concentrations at salinities below 30 may be smaller than Si incorporated in frustules (Fig. 8), in this way indicating the possibility of growth limitation by this element.

The smoothed curves of diatoms and flagellates are calculated in a log system and 


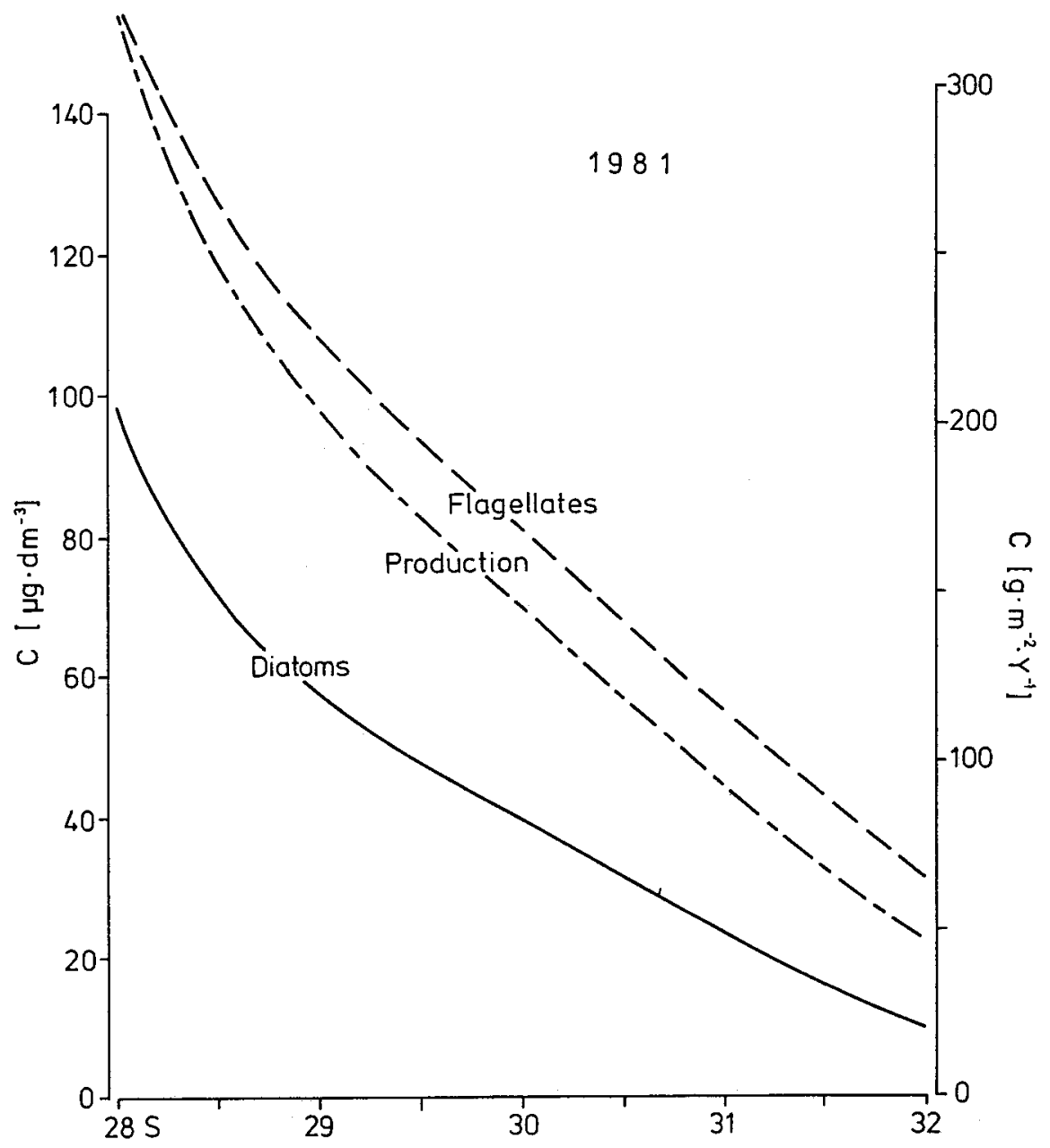

Fig. 11. Helgoland Roads 1981: annual means of diatoms and flagellates and the resulting produc-

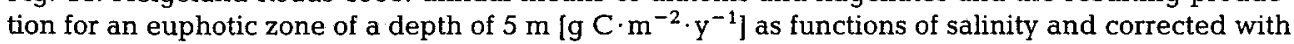
respect to the disturbances at the beginning of the year

afterwards corrected (Fig. 9; p. 445). They demonstrate only a slight connection with the nutrients (Fig. 7). It can be seen that the curves in the boundary regions, especially at the beginning of the year, are somehow disturbed. The log scale elucidates the relative fluctuations in time indicating that the pronounced bloom of peridinians has nothing to do with a high multiplication rate as the true indicator of good growth conditions, whilst the diatoms are much more active in this respect mainly at the beginning of the year. The absolute differences in the stocks during the annual cycle with respect to salinities and the differences between diatoms and flagellates are demonstrated better in a numerical scale (Fig. 10). There are no major differences between the maxima of diatoms and flagellates, whilst in both diatoms and flagellates the decreases of the maxima of the 


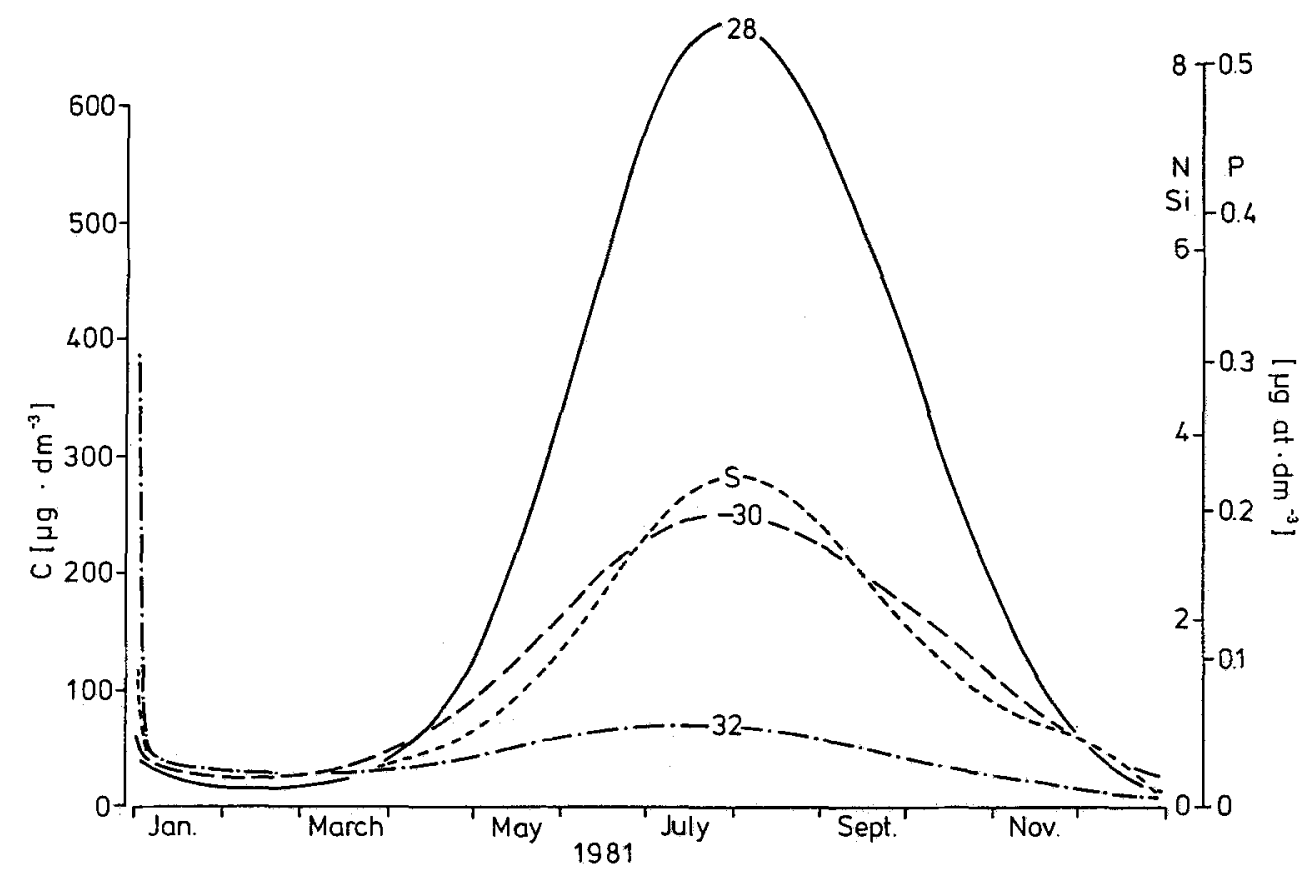

Fig. 12. Helgoland Roads 1981: smoothed annual cycles of the sums of (diatoms + flagellates) and of the quantities of P, N, and $\mathrm{Si}$ (diatoms only) incorporated in the organisms for the salinities 28, 30, and 32 and for the mean salinity curve given in Figure 6

stocks with increasing salinity are impressive. Daily productions under the assumption of a depth of the euphotic zone of five metres are given; they indicate reasonable values for such a region. These results can be used to calculate the mean annual quantities of diatoms and flagellates as functions of salinity (after correction with respect to disturbances at the beginning of the year) (Fig. 11). From these values, the annual production can be deduced. This method does not improve our knowledge on the mean yield in this region because it is not exact enough. The year investigated was an atypical one with respect to plankton stock, and the depth range suited for assimilation should increase with increasing salinity (reduced turbidity), thus simulating an excessive production gradient but giving a good impression of the connection between phytoplankton and coastal distance. Nevertheless, the results are comparable with other observations (Steele, 1958; Postma, 1973; Cadée, 1986).

Superposing the curves of diatoms and peridinians gives bellshaped structures with a special description of the plankton "development" near Helgoland observed by means of the salinity fluctuations (S) (Fig. 12), The scales of $\mathrm{C}$ and the incorporated quantities of $\mathrm{P}, \mathrm{N}$, and $\mathrm{Si}$ (diatoms only) may be compared with the respective inorganic concentrations in Figures 7 and 8.

As found out already, the relative increases and decreases of phytoplankton stock per day, normally more pronounced in the case of lower salinities (first derivative), are small compared with observations during true spring blooms (p. 440), especially with 


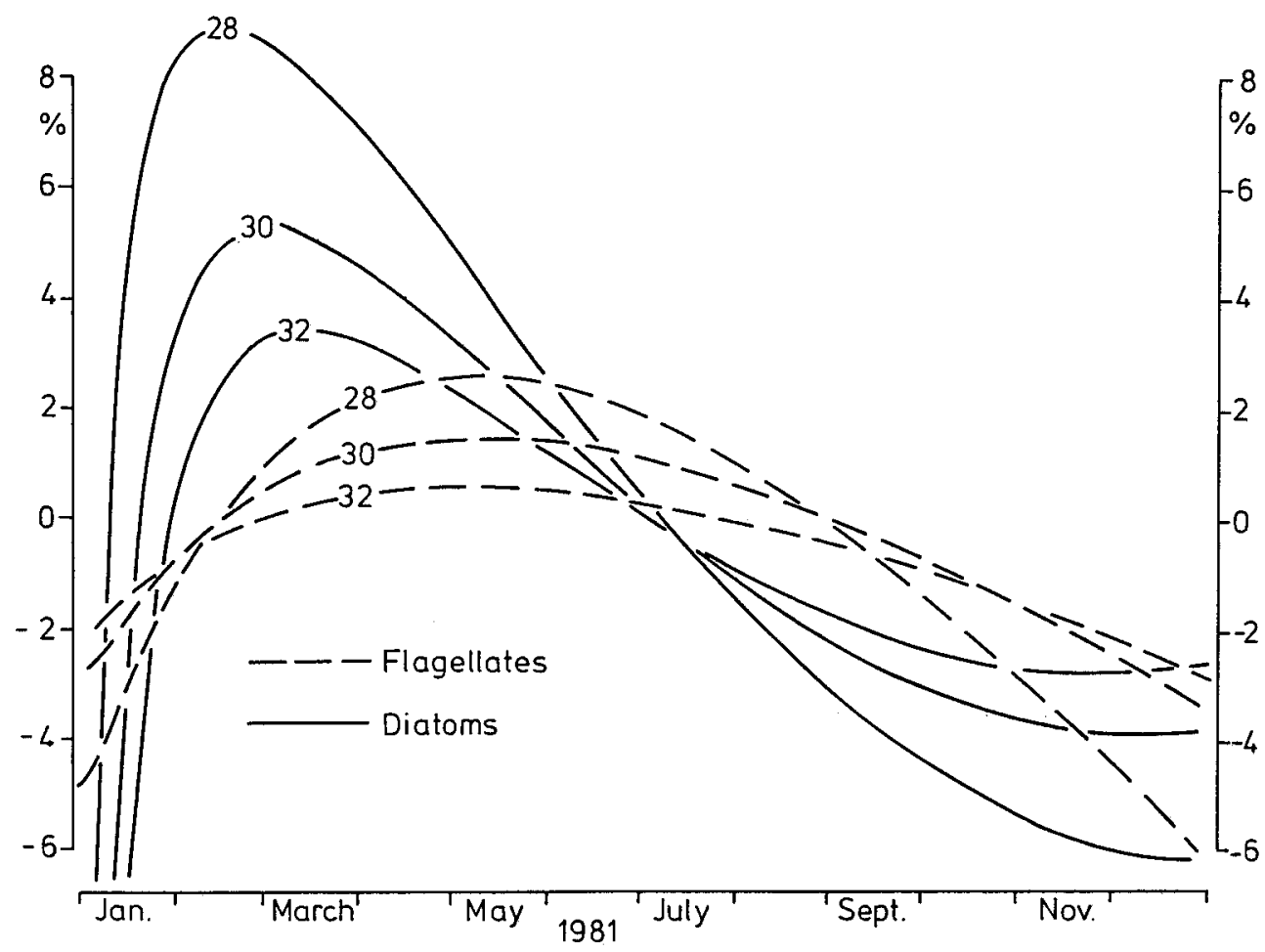

Fig. 13. Helgoland Roads 1981: smoothed annual cycles of the daily increases or decreases $(-)$ in \% of the stocks of diatoms and flagellates for the salinities 28,30 , and 32

respect to flagellates (Fig. 13). This means that the bloom has nothing to do with an explosion of the population but is the consequence of an extended growth period (diatoms) and a relatively large initial stock (flagellates) with a slow-speed decline afterwards. The respective absolute alterations (Fig. 14) are highest a short time before and after the maxima of the stocks, with highly differing values for different salinities, and with similar findings for diatoms and flagellates with a time lag of two months in between.

It is of some interest to investigate the turnover rates of the system in more detail by comparing the changes per day ( $\mathrm{P}, \mathrm{N}$, phytoplankton), and the calculated production, as carried out for $S=28$ in Figure 15a. The phytoplankton values are given inversely because production or an increase in phytoplankton stock means a decrease in nutrients in water. It can be seen that the fluctuations in the inorganic nutrient stocks have almost nothing to do with the level and time of production. This fact indicates the existence of a highly active remineralization system besides a direct uptake of nutrient compounds not determined by our methods. This complicated situation is the reason why the nutrient fluctuations observed (Fig. 7) are fairly independent of phytoplankton activity (Fig. 10), and are, as a consequence, relatively higher in the case of small production ( $\mathrm{S}=32$; Fig. 15b). It can be seen that a higher uptake rate of nutrients by higher phytoplankton 


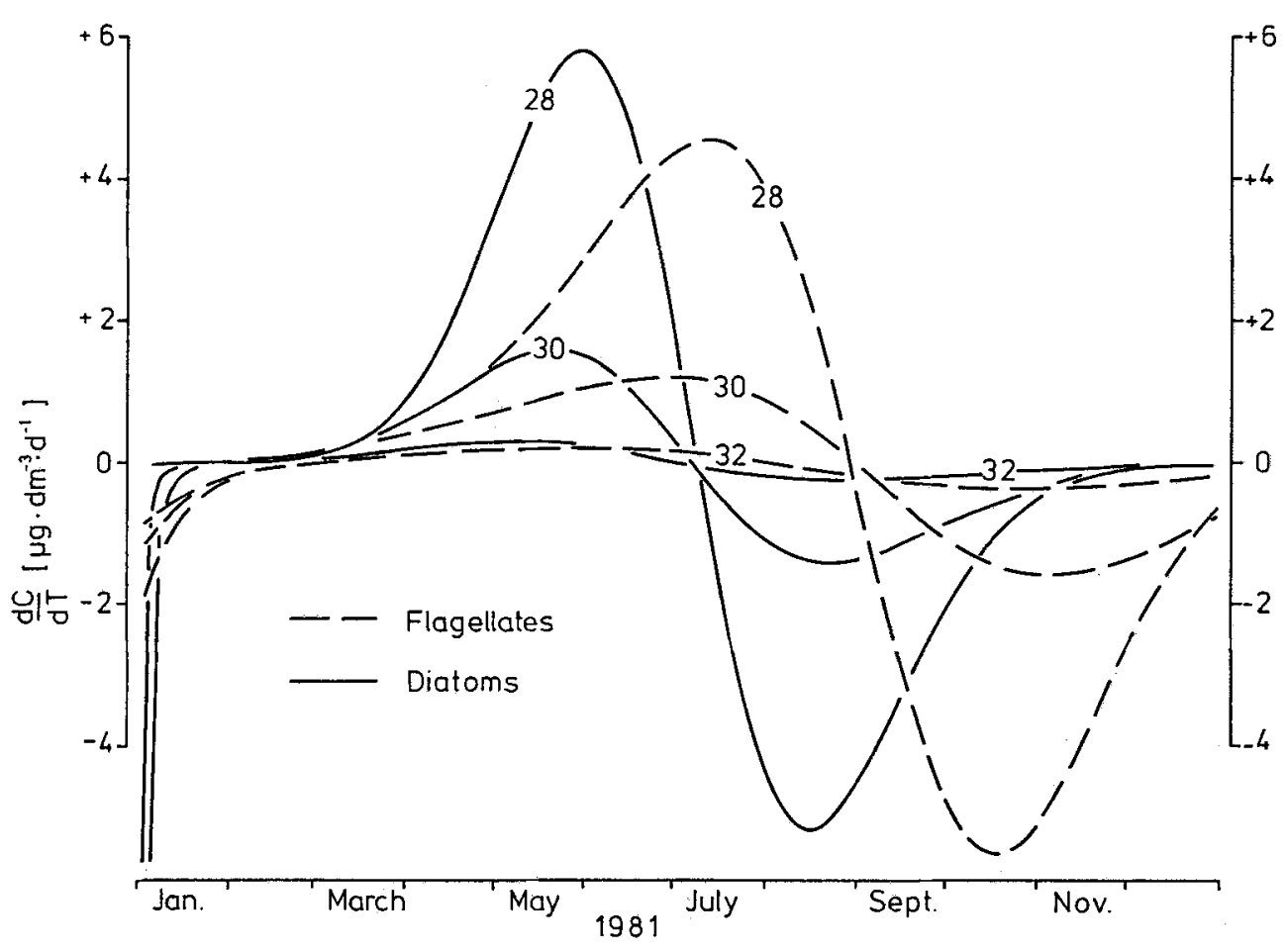

Fig. 14. Helgoland Roads 1981: smoothed annual cycles of the absolute daily increase $(+)$ or decrease $(-)$ of the stocks of diatoms and flagellates for the salinities 28,30 , and 32

production is compensated for by better remineralization after an initial period, especially of $P$, the concentration of which increases again at the time of maximal plankton production. The same tendency is shown by nitrogen, giving a phase difference between the different curves in such a way that $\mathrm{P}$ and $\mathrm{N}$ are always ahead of organic production. The development in this respect may be a function of the absolute concentration of organic nutrients, especially for the time span needed to produce optimal remineralization.

These facts regarding $\mathrm{P}$ and $\mathrm{N}$ can be explained. However, it is not so easy to understand the situation with respect to inorganic Si (organic Si compounds are rare in nature; Jørgensen, 1955b), which is incorporated practically only in the frustules of diatoms. In Figure 16 this is demonstrated, and even a more pronounced and permanently effective remineralization for $S=28$ and $S=32$ than demonstrated earlier for other nutrients including phase shifting etc. (p. 462).

Figure 17 summarizes the behaviour of diatoms and flagellates during the vegetation period in 1981. The log scale of phytoplankton quantities provides a good opportunity to compare the relative increases of stocks, given in differences between lowest values in winter for diatoms $\left(D_{L}\right)$ and flagellates $\left(F_{L}\right)$, and the respective maximal values in summer $\left(D_{H}\right.$ resp. $\left.F_{H}\right)$. These differences are much smaller for the latter than for the former and 

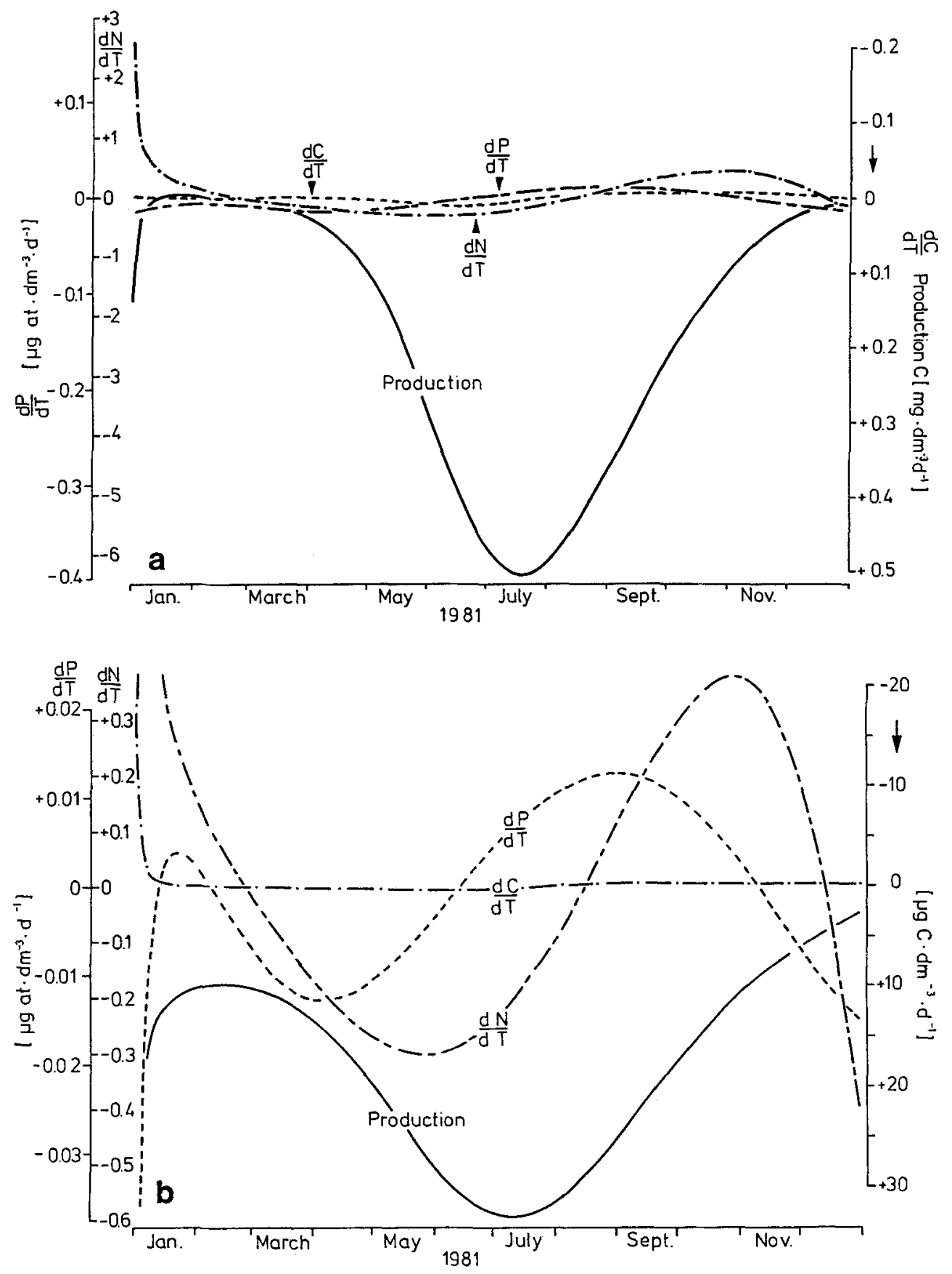

Fig. 15. Helgoland Roads 1981: a: $S=28, b: S=32$. Daily changes of phosphate (dP/dT), inorganically bound $\mathrm{N}(\mathrm{dN} / \mathrm{dT})$, and phytoplankton stock $(\mathrm{dC} / \mathrm{dT})$ as well as daily production of phytoplankton with the carbon scale inverse to the others 

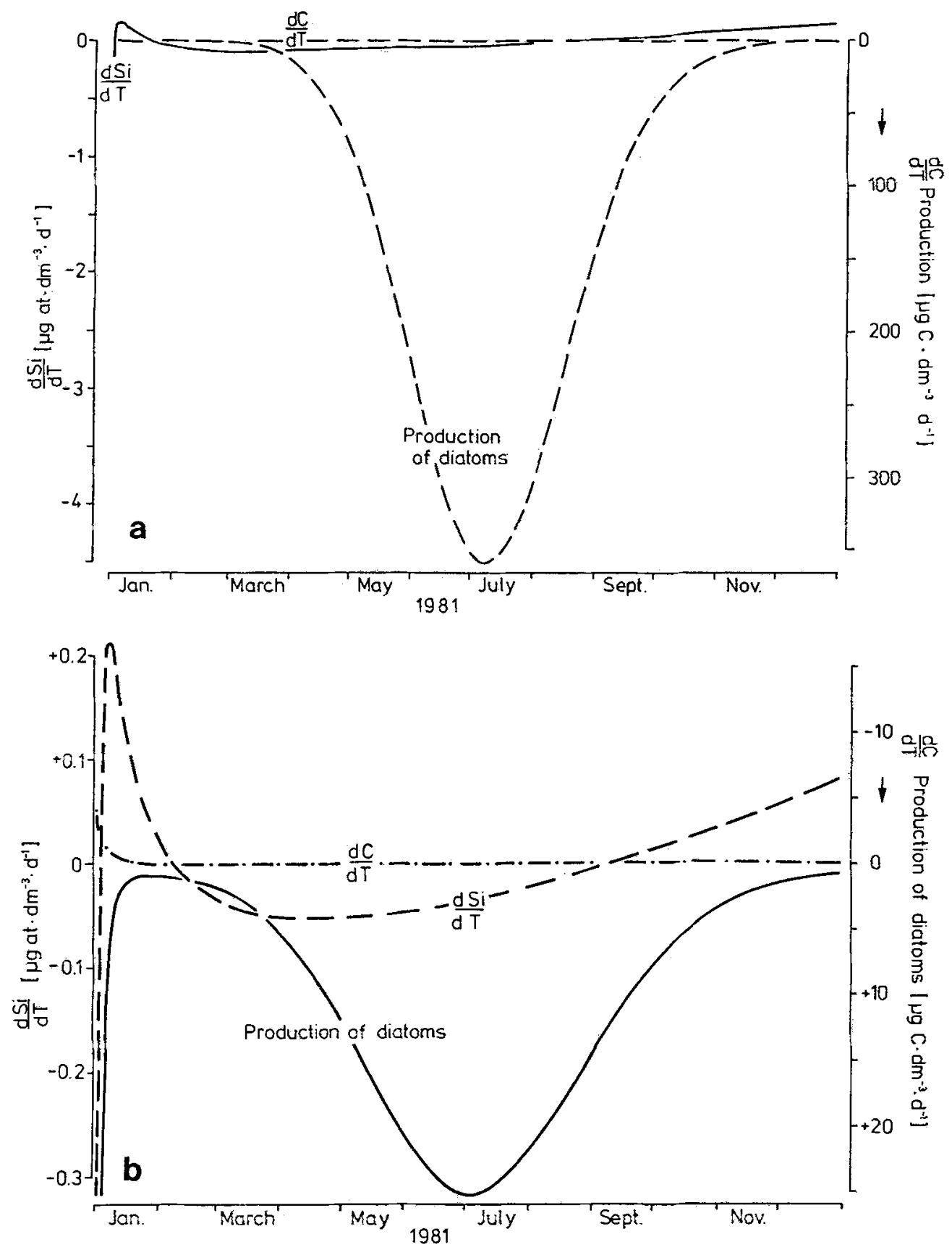

Fig. 16. Helgoland Roads 1981: a: $\mathrm{S}=28, \mathrm{~b}: \mathrm{S}=32$. Observed daily changes of silicate (dSi/dT) and diatom stock (dC/dT) as well as daily production of diatoms with the carbon scale inverse to the other 


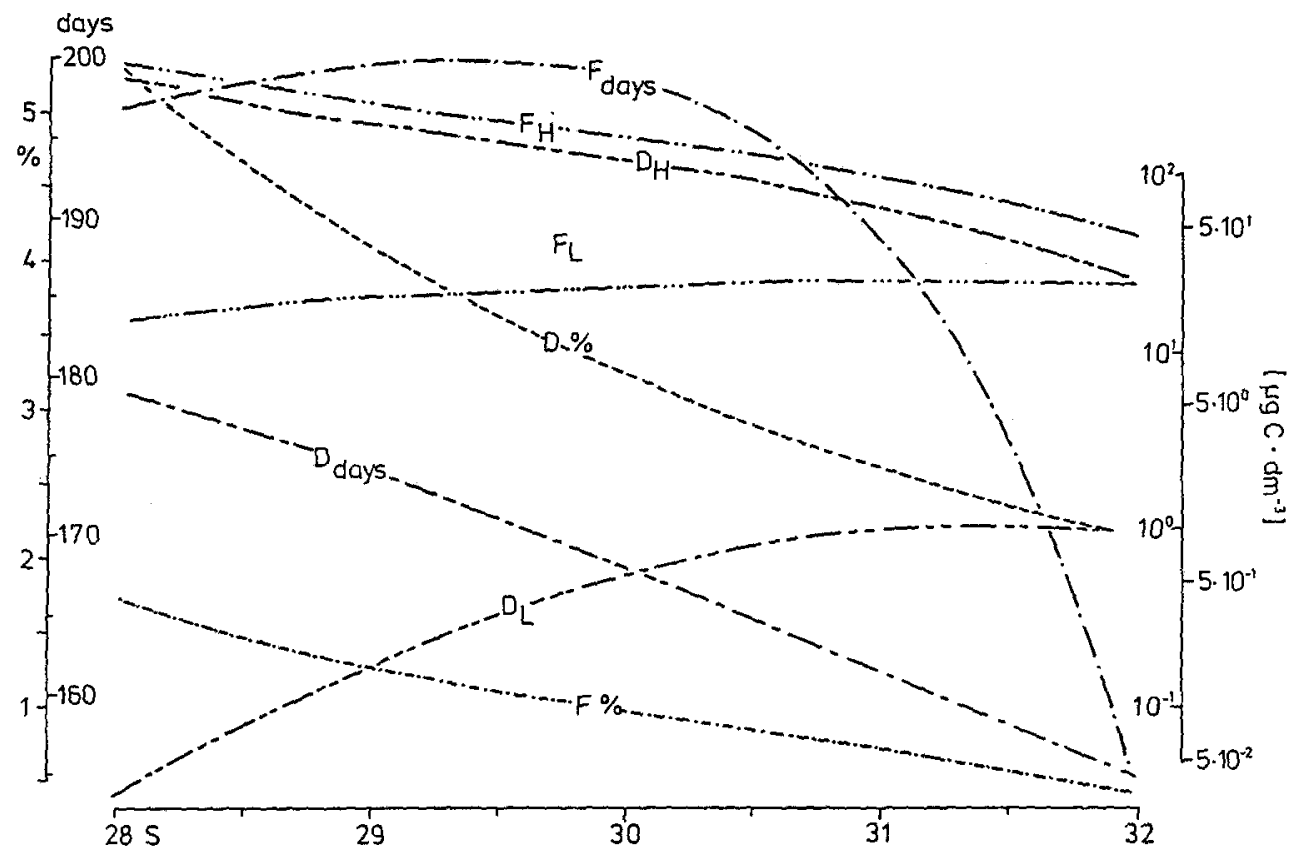

Fig. 17. Helgoland Roads 1981: phytoplankton development as a function of salinity; $D=$ diatoms; $F$ = flagellates; $L=$ lowest calculated value; $H=$ highest calculated value (log scale); days = number of days from minimum to maximum; \% = mean increase of phytoplankton stock (D or F) from day to day during this time

decrease with increasing salinity varying between the following extreme values: for diatoms and $S=28$ the multiplication rate during summer is 10000 , and for flagellates and $S=32$ less than two. Between 155 and 200 days or roughly half a year were necessary to produce these highly different results, which means a long permanent growth season for phytoplankton. This period is generally slightly longer for flagellates than for diatoms ( $F_{\text {days }}$ resp. $D_{\text {days }}$ ), and the resulting mean rate of increase per day ranged between 0.5 and $5.5 \%$ (F \% resp. D \%).

The dynamics of phytoplankton may be discussed in more detail taking the diatoms as subject, which are better known in this respect than flagellates, and starting with the following definitions (Table 3):

$\mathrm{I}=$ factor for daily increase of stock $=1$ in the case of a stable population (an improbable situation in reality); increase in $\%=(I-1) \cdot 100$.

$F_{p}=$ factor for daily gross production; respiration over $24 \mathrm{~h}=1 / 3 \cdot F_{p} ;$ therefore net production $=2 / 3 \cdot F_{p} ; F_{P}=1$ means daily production $=$ quantity of stock (assumed to be the fact in the case of $I=1$.

$F_{1}=$ factor for daily losses (except respiration) $=0.6$ (or the loss itself $=40 \%$ ) in the case of $I=1$ and $F_{P}=1$; the simple calculated daily increase $(D \approx$ diatom stock):

$$
D \cdot I=D \cdot\left(1+2 / 3 \cdot F_{P}\right) \cdot F_{1} \text {. }
$$

Results obtained in this way cannot be very correct for two reasons. Firstly, a single year is only one single year and does not give a description of a mean situation, which is 
Table 3. Dynamics of diatoms

\begin{tabular}{|c|c|c|c|c|c|}
\hline $\begin{array}{c}\text { Daily } \\
\text { increase } \\
(\%) \\
\text { (a) }\end{array}$ & $\begin{array}{l}\text { Days } \\
\text { (b) }\end{array}$ & $\begin{array}{l}\text { Daily gross } \\
\text { prod. } 1 \\
(\%) \\
\text { (c) }\end{array}$ & $\begin{array}{c}\text { Daily gross } \\
\text { prod. } 2 \\
(\%) \\
\text { (d) }\end{array}$ & $\begin{array}{c}\text { Daily } \\
\text { loss } 1 \\
(\%) \\
(\mathrm{e})\end{array}$ & $\begin{array}{l}\text { Daily } \\
\text { loss } 2 \\
\text { (\%) } \\
\text { (f) }\end{array}$ \\
\hline+25 & 31 & 162 & 117 & 25 & 30 \\
\hline+20 & 38 & 150 & 114 & 28 & 32 \\
\hline+15 & 49 & 138 & 110 & 31 & 34 \\
\hline+10 & 72 & 125 & 107 & 34 & 36 \\
\hline+5 & 142 & 112 & 104 & 37 & 37 \\
\hline \multirow{2}{*}{$\begin{array}{r}1 \\
0\end{array}$} & 694 & 102 & 101 & 39 & 40 \\
\hline & $\infty$ & 100 & 100 & 40 & 40 \\
\hline-1 & 688 & 98 & 99 & 41 & 40 \\
\hline-5 & 135 & 88 & 96 & 43 & 42 \\
\hline-10 & 66 & 75 & 93 & 46 & 44 \\
\hline-15 & 43 & 62 & 89 & 49 & 47 \\
\hline-20 & 31 & 50 & 85 & 52 & 49 \\
\hline-25 & 24 & 38 & 81 & 55 & 51 \\
\hline
\end{tabular}

(a) Daily increase $(+)$ or decrease $(-)$ of diatom stock given in $\%$.

(b) Number of days needed to get a $10^{3}$-fold stock increase or a $10^{-3}$-fold stock decrease.

(c) Daily gross production of stock $\left(F_{p}\right)$ given in \% under the assumption that daily loss is the same as for increase $0 \%\left(40 \%\right.$ or factor $\left.=F_{1}=0.6\right)$; respiration $=1 / 3$ gross production or net production $=2 / 3$ gross production.

(d) Daily gross production of stock given in $\%$ under the assumption that the relation $F_{1} / F_{P}$ is constantly 0.6 .

(e) Daily loss of (stock + net production) in \% under the assumption that daily production is the same as for increase $0 \%\left(100 \%\right.$ or $\left.F_{P}=1\right)$.

(f) Daily loss of stock given in \% under the assumption in (d).

an abstraction loosely bound to real observations in nature, because the development is diverse in every annual cycle (Fig. 4). Secondly, measurements are not taken often enough and are not complex enough to satisfy ail the statistical demands and all the questions asked to clarify such a multidimensional system. Is it really possible to solve such a problem to a satisfactory extent even under favourable conditions? The complicated procedures used in this investigation are therefore supplemented, for practical reasons, by assumptions and by data from literature. The results obtained in this way will be satisfactory with respect to trends, ranges, relations, and so on, but the absolute values should be discussed with caution. Variations in the daily increases of phytoplankton stocks (Table 3, Column a) have been investigated on a larger scale than observed here, but our observations do not contrast completely with observations made elsewhere $(+15 \%$ to $-25 \%)$ during spring blooms. The time span needed to get a reasonable increase or decrease (factor: 1000) of a plankton population is in the range of months under the conditions discussed here (Table 3, Column b). This means that a changed growth situation cannot be seen within a very short time, as is sometimes assumed (Gillbricht, 1983). But what does happen in the case of increase or decrease of a plankton 
stock by production and loss? Assuming that only one of these two factors changes whilst the other retains its value in the case of a zero increase $\left(F_{p}=1\right.$ or $F_{1}=0.6$, as given in Table 3 , Column $c$ and e), the increase (I) is much more sensitive to changes in losses than to changes in production, which can be seen by the greater relative differences of the latter compared with the former to get the same effect upon I. The practical consequence of this conclusion is that it is more realistic to state that phytoplankton is influenced to a greater extent by different losses (turbulence, sinking velocity, zooplankton) than by changing production. This result can be affirmed by a calculation under the assumption that $F_{1} / F_{P}=$ constant $=0.6$ : this means variations of both components in the same sense (Table 3, Column $d$ and f). Whilst the changes in Column (d) are small compared with Column (c), no such great differences are seen between Column (f) and (e). In this way, the higher controlling influence of loss is indicated. The weakness of this conclusion is that it is dependent on the formula given above. This reduces the accuracy of our findings. It is, for instance, not correct to calculate with a respiration rate of "zero" for non-assimilating phytoplankton as assumed before (p. 440). But it is not only the incomplete information of man that hinders the acquirement of more precise results about life in the sea. It is the sea itself, which changes its state permanently in many dynamic processes thus continually influencing marine organisms. This intense fluctuation of an unknown number of variable factors essential to life masks the significance of every single factor. This situation hinders or impedes, at least, the discovery of the true biological dynamics and its regulations in the sea. This fact has considerable theoretical and practical consequences.

\section{DISCUSSION}

The sea is a multiple system with numerous interrelations between different components where the proportionality between any two components may not only be linear but also e.g. logarithmic. The complex influence of many components may produce completely different effects; sometimes plus/minus reactions may be found (survival or death), and so on. Biological processes are especially sensitive in this respect. Small variations in the (exponential) growth rate of a population produce impressive differences in stock; and experimental results in small vessels cannot be easily extrapolated to describe the situation in the sea (Gillbricht, 1969); but they can be used to gradually gain new insight, when the practical value of the results obtained are weighed up realistically.

Simple formalistic statistics used in the investigations on nutrients and phytoplankton can give only a primitive picture of the situation, whereas negative findings are mainly valid for theoretical reasons. First of all, it is clear that neither $P$ nor $N$ could have limited the phytoplankton growth in 1981, because both of them were always available to a sufficient extent (p. 447). This is not the effect of a great nutrient stock, but of a highly dynamical process (Ketchum, 1947), as can be seen in Table 4 . The minimal turnover time of $\mathrm{P}$ and $\mathrm{N}$ (inorganic nutrient concentration/phytoplankton production) given in days is long compared with observations in limnic systems (Taft et al., 1975), and is observed about the time of the phytoplankton maximum.

Higher values give the minimal quotients (inorganic nutrient concentration/first derivative) observed earlier in the year: 
Table 4. Helgoland Roads 1981: Minimal turnover time of nutrients

\begin{tabular}{|c|c|c|c|c|c|c|}
\hline \multirow[b]{3}{*}{ Salinity } & \multicolumn{4}{|c|}{$\begin{array}{c}\text { Phosphate } \\
P^{\prime}=d P / d T\end{array}$} & \multirow{2}{*}{\multicolumn{2}{|c|}{ - $\left(\mathrm{P} / \mathrm{P}^{\prime}\right)$}} \\
\hline & \multicolumn{3}{|c|}{ P/Production } & \multirow[b]{2}{*}{ Date } & & \\
\hline & Date & & Days & & & Days \\
\hline 28 & July & 8 & 1.7 & May & 3 & 78 \\
\hline 30 & June & 28 & 3.1 & May & 5 & 60 \\
\hline 32 & June & 18 & 6.7 & May & 9 & 45 \\
\hline \multicolumn{7}{|c|}{$\begin{array}{c}\Sigma(\text { Inorganically bound N) } \\
N^{\prime}=d N / d T\end{array}$} \\
\hline & \multicolumn{3}{|c|}{ N/Production } & \multicolumn{3}{|c|}{$-\left(N / N^{\prime}\right)$} \\
\hline 28 & July & 31 & 3.2 & June & 22 & 101 \\
\hline 30 & August & 6 & 5.9 & June & 29 & 77 \\
\hline 32 & August & 11 & 8.1 & July & 15 & 40 \\
\hline \multicolumn{7}{|c|}{$\begin{array}{l}\text { Silicate } \\
\mathrm{Si}^{\prime}=\mathrm{dSi} / \mathrm{dT}\end{array}$} \\
\hline & \multicolumn{3}{|c|}{ Si/Production } & \multicolumn{3}{|c|}{$-\left(\mathrm{Si} / \mathrm{Si}^{\prime}\right)$} \\
\hline 28 & July & 30 & .44 & July & 4 & 59 \\
\hline 30 & August & 7 & 1.2 & July & 13 & 63 \\
\hline 32 & August & 11 & 5.6 & July & 15 & 68 \\
\hline
\end{tabular}

$$
\begin{gathered}
\left(\mathrm{T}=\text { time, } \mathrm{P}^{\prime}=\mathrm{dP} / \mathrm{dT}, \mathrm{N}^{\prime}=\mathrm{dN} / \mathrm{dT}, \mathrm{Si}^{\prime}=\mathrm{dSi} / \mathrm{dT}\right) \\
-\left(\mathrm{P} / \mathrm{P}^{\prime}\right) \text { resp. }-\left(\mathrm{N} / \mathrm{N}^{\prime}\right) \text { resp. }-\left(\mathrm{Si} / \mathrm{Si}^{\prime}\right)
\end{gathered}
$$

thus demonstrating the significance of permanent remineralization.

These findings do not indicate any nutrient limitation in this region, with better growth conditions for phytoplankton nearer the coast in the salinity range observed. This latter result cannot be extrapolated to the shore; Elbrächter (pers. comm.) could not detect a Ceratium bloom close to the island Sylt. This comes as no surprise because great turbidity of the water reduces the light intensity, thus hindering phytoplankton growth, especially in flat regions with strong (tidal) currents (Postma, 1973; Cadée, 1986). In contrast, turbidity in the open sea is produced first of all by the plankton itself and - to a higher degree - by its decomposition products (detritus) (Gillbricht, 1959). On the other hand, a mass development of Phaeocystis was observed at the same time (Eberlein et al., 1985) and in other years (Bätje \& Michaelis, 1986) near the coast, accompanied by impressive sea foam caused by the production of substances that reduce the surface tension; such substances were detected in smaller quantities by Nansen (1902) in Arctic waters, and they coincide with phytoplankton near Helgoland throughout the year (Goedecke, 1956; Gassmann \& Gillbricht, 1982). The fact that this species exists only near the coast is not typical, as could be seen in the Greenland area (Gillbricht, 1959), and spectacular phytoplankton blooms near the shore may occur from time to time anywhere. Steuer (1910) reported on a mass development of blue-green algae in the Baltic in 1855 producing walls of decaying remains of these organisms on the beach of the island 
Gotland. Life is too complex to be explained by simple formula; our knowledge is incomplete; not every situation has been investigated. However, calculations do give the impression that extreme mass developments. near the coast (low salinity) need more nutrients than are available merely by admixture of seawater.

Freshwater is often poor in natural nutrients compared with seawater (p. 436), with the consequence that in mixing zones the possible maximum of phytoplankton stock may be limited by lack of nutrients (Sakshaug \& Olsen, 1986). The situation is different off highly populated coasts (Kalle, 1953), as discussed here with no exact knowledge of the "natural" nutrient content of freshwater. There is, however, sufficient information on nutrients in the inflowing seawater, which can be calculated with $\approx 0.75 \mu \mathrm{g}$ atom $\mathrm{P} \cdot \mathrm{dm}^{-3}$ resp. $\approx 11 \mu \mathrm{g}$ atom $\mathrm{N} \cdot \mathrm{dm}^{-3}$ from the data given by Postma (1973), in agreement with Johnston \& Jones (1965). These quantities in water of $S=35$ are diluted in proportion to the admixture of freshwater. To a certain degree, however, they are transformed into organic compounds, to be used partly at least by phytoplankton and partly lost by sedimentation in the freshly imported seawater near the coast (counter-clockwise circulation). These losses in the old water of the Central North Sea may be greater over a longer time span. They do not hinder, however, the building-up of reasonable blooms of coccolithophorids in this region, as observed e.g. by the author in 1975. The organically bound nutrients may exist in a form that cannot be used or can be used only with difficulty by photoplankton. There are certain loopholes in our knowledge with regard to this; we do not know, therefore, what quantity of nutrients coming from the sea to this region is reasonably available for phytoplankton. The problem, nutrient and freshwater, is also complicated to a certain degree. Total nutrient is not a conservative component in a strict sense, and there are special complications: freshwater does not mix directly with seawater, but may be chemically transformed during its passage through the turbidity zones at the mouths of the rivers (Postma \& Kalle, 1955) and during the crossing of the interconnected Wadden seawater between the chain of islands and the mainland (Gillbricht, 1956).

The situation with respect to phosphorus and phytoplankton is described in Table 5. For different salinities (Table 5, Column a) the necessary $\mathrm{P}$ content of freshwater is calculated to produce the maximum in winter $\left(\mathrm{PO}_{4}+\right.$ phytoplankton) by mixing with a nutrient-free seawater (Column b). The results are in reasonable agreement with the values calculated from the data given by Postma (1973) of $18 \mu \mathrm{g}$ atom $\cdot \mathrm{dm}^{-3}$, and by ARGE Elbe (1982) for 1981 of $10 \mu \mathrm{g}$ atom $\cdot \mathrm{dm}^{-3}$. The maximal P content of phytoplankton (Table 5 , Column c) is relatively small and can therefore be compared with the P concentration gained by mixing seawater with a nutrient-free freshwater (as an unrealistic theoretical supposition). Column (d) assumes for this mixture the $P$ value of inflowing seawater; this concentration may be too high, because certain losses must be expected, and a small surplus of $P$ compared with the quantity incorporated in phytoplankton may be necessary. Therefore calculations of $2 / 3$ (Column e) and $1 / 2$ (Column $f$ ) of maximal $P$ concentration are given, thus, probably, including realistic quantities. It can be seen that only water of low salinity has $\mathrm{P}$ concentrations in these calculations that are too small for such an extreme phytoplankton bloom. This effect is strengthened by the exponential increase of phytoplankton stock towards the coast. This situation can be hindered nearer the shore by lack of nutrients due to the nutrient-poor freshwater input. It may be regulated in this region by high turbidity near the shore (p. 459), maybe with different reactions of 
Table 5. Helgoland Roads 1981: phosphorus $\left[\mu \mathrm{g}\right.$ at $\cdot \mathrm{dm}^{-3}$ ] in water and phytoplankton, calculated mixing conditions under different assumptions. $P_{S}=$ phosphorus in seawater $(S=35) ; P_{F}=$ phosphorus in freshwater $(\mathrm{S}=0) ; \mathrm{P}=$ phosphorus in mixed water or phytoplankton

\begin{tabular}{|c|c|c|c|c|c|c|}
\hline & $\begin{array}{l}\text { Salinity } \\
\qquad \begin{array}{c}\text { S } \\
\text { (a) }\end{array}\end{array}$ & $\begin{array}{c}\text { Winter } \\
P_{S}=0 \\
P_{F} \\
\text { (b) }\end{array}$ & $\begin{array}{l}\text { Phyto- } \\
\text { plankton } \\
\text { P } \\
\text { (c) }\end{array}$ & $\begin{array}{c}P_{F}=0 \\
P_{S}=0.75 \\
\text { (d) }\end{array}$ & $\begin{array}{c}P_{F}=0 \\
P_{S}=0.5 \\
(e)\end{array}$ & $\begin{array}{c}P_{F}=0 \\
P_{S}=0.375 \\
\text { (f) }\end{array}$ \\
\hline & 28 & 9 & 0.53 & 0.60 & 0.40 & 0.30 \\
\hline & 30 & 11 & 0.20 & 0.64 & 0.43 & 0.32 \\
\hline & 32 & 16 & 0.05 & 0.69 & 0.46 & 0.34 \\
\hline & Salinity & $\begin{array}{c}\text { P in } \\
\text { Phytopl. } \\
P_{F}=0 \\
P_{S} \\
(g)\end{array}$ & & & $\begin{array}{c}\text { P in } \\
\text { Phytopl. } \\
P_{S}=0.375 \\
P_{F} \\
\text { (i) }\end{array}$ & $\begin{array}{c}\text { P in } \\
\text { Phytopl. } \\
P_{S}=0.5 \\
P_{F} \\
(k)\end{array}$ \\
\hline & 28 & 0.66 & & & 0.76 & 0.13 \\
\hline & 30 & 0.23 & & & - & - \\
\hline & 32 & 0.05 & & & - & - \\
\hline (b) & \multirow{9}{*}{\multicolumn{6}{|c|}{$\begin{array}{l}P_{F} \text { necessary to produce the } P \text { concentration observed (phytoplankton }+P_{4} \text {, mean from } \\
\text { winter and autumn without the disturbance at the beginning of the year, Fig. } 7 \text { ) under the } \\
\text { assumption } P_{S}=0 \text {. } \\
\text { Maximal phosphorus content of phytoplankton. } \\
P_{S}=0.75, P_{F}=0 \text {, calculated } P \text { contents at different salinities by mixing. } \\
P_{S}=0.5, P_{F}=0 \text {, calculated } P \text { contents at different salinities by mixing; concentration smaller } \\
\text { than maximal } P \text { content of phytoplankton given in bold print. } \\
P_{S}=0.375, P_{F}=0 \text {, calculated } P \text { contents at different salinities by mixing: concentration } \\
\text { smaller than maximal } P \text { content of phytoplankton given in bold print. } \\
P_{F}=0, P_{S}=P \text { content in seawater necessary to produce a concentration equal to } P \text { content in } \\
\text { maximal phytoplankton stock in mixed water. } \\
P_{S}=0, P_{F}=P \text { content in freshwater necessary to produce a concentration equal to } P \text { content } \\
\text { in maximal phytoplankton stock in mixed water. } \\
P_{S}=0.375, P_{F}=P \text { content in freshwater necessary to produce a concentration equal to } P \\
\text { content in maximal phytoplankton stock in mixed water. } \\
P_{S}=0.5, P_{F}=P \text { content in freshwater necessary to produce a concentration equal to } P \\
\text { content in maximal phytoplankton stock in mixed water. }\end{array}$}} \\
\hline (c) & & & & & & \\
\hline (d) & & & & & & \\
\hline (e) & & & & & & \\
\hline (f) & & & & & & \\
\hline (g) & & & & & & \\
\hline (h) & & & & & & \\
\hline (i) & & & & & & \\
\hline (k) & & & & & & \\
\hline
\end{tabular}

different species in this respect. The $\mathrm{P}$ content necessary to produce mixed water with $\mathrm{a}$ concentration equal to the maximal phytoplankton stock, under the condition that seawater is mixed with nutrient-free freshwater or vice versa, is given in Table 5 (Column $\mathrm{g}$ and $\mathrm{h}$ ). A small nutrient demand also in a region near the coast is indicated. Assuming a certain quantity of $\mathrm{P}$ in seawater reduces the $\mathrm{P}$ content of freshwater necessary for the growth of an extreme quantity of phytoplankton as seen in Table 5 (Column $\mathrm{i}$ and $\mathrm{k}$ ). Similarly, if we set aside the fact that some $\mathrm{P}$ reserve is necessary besides the quantity incorporated into phytoplankton, the approximated concentration of P necessary for good development of plankton can be deduced by this method. It is of special interest whether or not growth conditions can become so optimal one day that a plankton stock can be 
produced needing more nutrients than discussed. Such an event is outside of our experience. It may happen sometime, with the limitation that greater populations near the coast must limit further development by. self-made, direct or indirect increase of turbidity. The time span needed to build up a great plankton stock cannot, however, be greatly prolonged in our latitudes.

Silicate presents a special problem in this respect (Fig. 16; Table 4). Similar to the situation with $P$ or $N$, the consumption of $\mathrm{Si}$ is much higher than the decrease in nutrient stock; there are, however, other reasons for this (no incorporation into organic substances). Only a permanent restitution of losses on a large scale is, however, able to explain the situation. A nearly constant, small $\mathrm{Si}$ concentration must not necessarily be the minimum factor in such a dynamic system. The only portion of phytoplankton that needs Si (practically) is the diatom population. It could be regulated in this way separately as discussed since the beginning of plankton research (Brandt, 1902). The concentration of $\mathrm{Si}$ is small compared with that of other nutrients, and with demand (Figs 7 and 8). The solution necessary for the dynamics observed (Fig. 16) - especially with respect to the large spring bloom in 1985 (p. 447) - is not found in experiments: dead diatoms release a daily amount of only 0.5 to $1 \%$ of Si bound in the frustules (Jørgensen, 1955b), which is not enough to maintain a long lasting bloom. The silicon of living cells is practically insoluble, with solubility increasing by means of heating, EDTA, etc., optimized by treating with nitric acid, thus obtaining a fast solution of Si (Lewin, 1961). It could be demonstrated that frustules are protected by metal compounds. An organic coating, as discussed by Cooper (1952), was not detected.

These results explain the findings in this investigation to a certain extent only. Moreover, the Si content of diatoms was seen to be reduced under critical conditions, e. $\mathrm{g}$. in culture (Paasche, 1973); cell numbers continue to increase even after removal of $\mathrm{Si}$ (Jørgensen, 1955a). This indicates a significant dynamic force in the system that is not seen directly. If these findings are correct, they may indicate that the calculated $\mathrm{Si}$ consumption by diatoms is too high (Fig. 16) but correct in principle. To investigate this problem once more, the following points were considered:

(a) Phosphorus, nitrogen, and silicon are needed by phytoplankton over a short time during the vegetation period in greater quantities than those observed in inorganic form in the water.

(b) The quantities of nutrients incorporated in phytoplankton are much smaller than the quantities observed in water in winter time.

(c) Nevertheless the sum (inorganic nutrients observed + nutrients in plankton) is smaller in summer than in winter. With respect to $P$ and $N$, the difference is compensated largely by dissolved (and particulate) organic compounds.

Such a system needs fast short-cut regeneration processes. These are not directly demonstrable by nutrient measurements or are demonstrable to a minor degree only during the biologically active time of the year. With respect to $P$ and $N$, no problem exists in principle, but what happens with silicon? Where does it disappear to and from where does it come afterwards if needed? Two simple assumptions for the discussion of this problem are as follows:

(a) Remineralization is controlled by the volume of a - maybe unknown - depot. This effect has something to do with the difference between inorganic nutrient, winter maximum and summer minimum. 
(b) There is a constant nutrient concentration always buffered by a depot.

As can be seen clearly in Table 6 , the situation of $N$ can be described as (too) good by assumption a. The difference is independent of the different plankton activities at different salinities $(Q)$, whilst the minimum value is not constant. The situation with $P$ is

Table 6. Helgoland Roads 1981: Low est nutrient concentrations in summer (L) and nutrient decrease from winter maximum to summer minimum (D) of silicate (Si), phosphate (P), and inorganically bound nitrogen $(\mathrm{N})$ given in $\left[\mu \mathrm{g}\right.$ at $\left.\cdot \mathrm{dm}^{-3}\right]$ for different salinities $(S), Q=$ the quotient (highest value/lowest value) of every column

\begin{tabular}{|ccccccc|}
\hline $\mathrm{S}$ & $\mathrm{Si}_{\mathrm{L}}$ & $\mathrm{Si}_{\mathrm{D}}$ & $\mathrm{P}_{\mathrm{L}}$ & $\mathrm{P}_{\mathrm{D}}$ & $\mathrm{N}_{\mathrm{L}}$ & $\mathrm{N}_{\mathrm{D}}$ \\
\hline 28 & 1.39 & 13.4 & 0.631 & 1.30 & 18.8 & 32.5 \\
30 & 1.20 & 9.97 & 0.398 & 1.12 & 12.5 & 33.2 \\
32 & 1.13 & 7.55 & 0.235 & 1.01 & 4.24 & 33.3 \\
\hline $\mathrm{Q}$ & 1.24 & 1.78 & 2.69 & 1.29 & 4.43 & 1.02 \\
\hline
\end{tabular}

not so clear, but the decreases are more similar than the minimal values. This finding is in agreement with a better remineralization in the case of poor $P$ concentrations (p. 438). In contrast to these observations, the behaviour of $\mathrm{Si}$ can be explained best by acceptance of a buffering system (assumption b) not detected by our methods.

These considerations can only demonstrate the principle: the situation is too complicated. These findings, however, are in agreement with observations by Cooper (1933), who detected a nearly equal decrease of $\mathrm{P}$ and $\mathrm{N}$ with respect to the composition of organisms, whilst the Si stock changed to a smaller degree. This is the result, probably, of a more successful regeneration. No doubt, the fluctuations of inorganic nutrient concentrations observed are the tops of icebergs only, in comparison with the dynamic processes going on behind these small differences. But what sort of depot permanently restores $\mathrm{Si}$ losses to a stable minimum concentration of $1.2 \mu \mathrm{g}$ atom $\mathrm{Si} \cdot \mathrm{dm}^{-3}$ over a relatively long period of time (Fig. 8)? More clarity in this respect may be given by the reflections of Cooper (1952) on the different modifications of Si compounds in the water in equilibrium with one other and therefore counteracting the silicate consumption of diatoms (buffered system). On the other hand, Hart $(1934,1942)$ made some observations in the northern part of the Antarctic seas indicating certain growth limitations, especially a relative increase of spineless Corethron cells, with decreasing Si concentration.

The question is whether the small quantity of Si observed can be used effectively by diatoms. Such an assumption should be in reasonable agreement with the results of some culture experiments (Goering et al., 1973), bearing in mind the problems of such a comparison. This finding does not exclude the possibility of an influence of Si concentration upon species composition of the populations because of different demands in this respect (Paasche, 1973).

In coastal regions, the influence of the bottom upon the nutrient system must be considered. Slight fluctuations of the total nutrient content are observed over the year (Table 1) - at least in the waters of the Southern North Sea and the English Channel. This finding may deny the essential influence of sedimentation processes since decaying 
organic particles release $\mathrm{P}$ and $\mathrm{N}$ in the form of dissolved inorganic and organic components that reach the bottom in a highly modified chemical form (p. 438). As a consequence, nutrients in spring are generally not lost from the system but are used several times by phytoplankton before settling on the sediment after a much longer time span. Here the greatest portion is remineralized and redistributed into the water especially under unstratified winter conditions. This simple explanation may be modified by a reasonable exchange between sediment and water as summarized by Zeitzschel (1980) especially in flat regions with strong tidal currents, but with the problem of the relatively stable total nutrient concentration in water. The situation is similar with respect to $\mathrm{Si}_{\text {, }}$ because the greater quantity of this element exists in the bottom in an insoluble form (quartz) in contrast to the easily soluble silicate (Cooper, 1952).

There are more problems concerning remineralization than discussed up to now. The parallelism of nitrogen curves for different salinities (Fig. 7) compared with very different quantities of phytoplankton and production (Fig. 11) indicates reasonable differences in the nutrient dynamics. The development in time of the destroying system (bacteria) regulated by the quantity of (dissolved) organic matter may have produced this result, but one must bear in mind that the statistics used may also have influenced this finding to a certain degree. In contrast to this observation, phosphate demonstrates a tendency to decrease in amplitude during the annual cycle with regard to smaller total P concentrations (Table 6). This looks like a regulation induced by a certain shortage. We must not accord too much weight to this observation, as the P system easily acts in this way. A true limitation of $\mathrm{P}$ and $\mathrm{N}$ should produce cycles like $\mathrm{Si}$. No doubt, the quantities of $\mathrm{P}$ and $\mathrm{N}$ are much higher than necessary to build up the phytoplankton stock. The only question is, which portion of organically bound nutrients is needed to secure remineralization, thus increasing the inorganic $\mathrm{P}$ and $\mathrm{N}$ concentrations observed parallel with great plankton stocks. These findings indicate that this indispensable nutrient surplus $(P, N)$ is small compared with the actual situation in this area.

In any discussion on phytoplankton and nutrients one must bear in mind that these substances present a complicated problem due to complex dynamic processes that are difficult to study, highly unknown, and not to be explained by simple comparisons of static situations.

Acknowledgements. This investigation of long duration was carried out with the collaboration of numerous people including the crews of the research vessels and many colleagues of the "Biologische Anstalt Helgoland" on the island of Helgoland. P. Mangelsdorf and K. Treutner, technical assistants of long standing experience, produced the highly qualified data set necessary for all further calculations. Thanks are due to B. Freier for the assistance needed daily in compiling this paper, from data handling to updating the collection of literature; also to Dipl. Bibl. I. Schritt and Dipl. Bibl. B. Sysoew for their painstaking accuracy in correcting the "Literature cited". C. Berger improved the English text, and J. Marschall produced the drawings. Now that I am at the end of my official service I should like to thank them all cordially for their patient cooperation.

\section{LITERATURE CITED}

ARGE Elbe, 1982. Wassergütedaten der Elbe von Schnackenburg bis zur See 1981. - Wassergütestelle Elbe, Hamburg, $80 \mathrm{pp}$.

Armstrong, F. A. J. \& Harvey, H. W., 1950. The cycle of phosphorus in the waters of the English Channel. - J. mar. biol. Ass, U. K. 29, 145-162. 
Baars, J. W. M., 1981. Autecological investigations on marine diatoms. 2. Generation times of 50 species. - Hydrobiol. Bull. 15, 137-151.

Bätje, M. \& Michaelis, H., 1986. Phaeocystis pouchetii blooms in the East Frisian coastal waters (German Bight, North Sea). - Mar. Biol. 93, 21-27.

Baur, E., 1902. Ueber zwei denitrificirende Bakterien aus der Ostsee. - Wiss. Meeresunters. (Abt. Kiel) 6, 9-21.

Bennekom, A. J. van, Gieskes, W. W. C. \& Tijssen, S. B., 1975. Eutrophication of Dutch coastal waters. - Proc. R. Soc. Lond. (B) 189, 359-374.

Birge, E. A. \& Juday, C., 1926. Organic content of lake water. - Bull. Bur. Fish., Wash. 42, $185-205$.

Braarud, T. \& Føyn, B., 1931. Beiträge zur Kenntnis des Stoffwechsels im Meere. - Avh. norske VidenskAkad. Oslo. (Mat.-nat. Kl.) 14, 1-24.

Brandt, K., 1899. Ueber den Stoffwechsel im Meere. - Wiss. Meeresunters. (Abt. Kiel) 4, 213-230.

Brandt, K., 1902. Ueber den Stoffwechsel im Meere. 2. Abhandlung. - Wiss. Meeresunters. (Abt. Kiel) 6, 23-79.

Brandt, K. \& Raben, E., 1920. Zur Kenntnis der chemischen Zusammensetzung des Planktons und einiger Bodenorganismen. - Wiss. Meeresunters. (Abt. Kiel) 19, 175-210.

Butler, E. I., Knox, S. \& Liddicoat, M. I., 1979. The relationship between inorganic and organic nutrients in the sea water. - J. mar. biol. Ass. U. K. 59, 239-250.

Cadée, G. C., 1986. Increased phytoplankton primary production in the Marsdiep area (Western Dutch Wadden Sea). - Neth. J. Sea Res. 20, 285-290.

Chapra, S. C. \& Robertson, A., 1977. Great Lakes eutrophication: The effect of point source control of total phosphorus. - Science, N. Y. 196, 1448-1450.

Cooper, L. H. N., 1933. Chemical constituents of biological importance in the English Channel, November 1930 to January 1932. Part II. Hydrogen ion concentration, excess base, carbon dioxide, and oxygen. - J. mar. biol. Ass. U. K. 18, 729-753.

Cooper, L. H. N., 1952. Factors affecting the distribution of silicate in the Northern Atlantic Ocean and the formation of North Atlantic deep water. - J. mar. biol. Ass. U. K. 30, 511-526.

Eberlein, K., Leal, M. T., Hammer, K. D. \& Hickel, W., 1985. Dissolved organic substances during a Phaeocystis pouchetii bloom in the German Bight (North Sea). - Mar. Biol. 89, 311-316.

Elbrächter, M., 1977. On population dynamics in multi-species,cultures of diatoms and dinoflagellates. - Helgoländer wiss. Meeresunters. 30, 192-200.

Fleming, R. H., 1939. Composition of plankton and units for reporting populations and production. Proc. 6th Pacif. Sci. Congr. 3, 535-540.

Flynn, K. J. \& Butler, I., 1986. Nitrogen sources for the growth of marine microalgae: role of dissolved free amino acids. - Mar. Ecol. Prog. Ser. 34, 281-304.

Fogg, G. E., 1958. Extracellular products of phytoplankton and the estimation of primary production. - Rapp. P.-v. Réun. Cons. int. Explor. Mer 144, 56-60.

Gassmann, G. \& Gillbricht, M., 1982. Correlations between phytoplankton, organic detritus and carbon in North Sea waters during the Fladenground Experiment (FLEX 76). - Helgoländer Meeresunters. 35, 253-262.

Gillbricht, M., 1952. Untersuchungen zur Produktionsbiologie des Planktons in der Kieler Bucht II: Die Produktionsgröße. - Kieler Meeresforsch. 9, 51-61.

Gillbricht, M., 1955. Wucherungen von Phytoplankton in einem abgeschlossenen Hafenbecken. Helgoländer wiss. Meeresunters. 5, 141-168.

Gillbricht, M., 1956. Die Hydrographie des Jadebusens und der Innenjade. - Veröff. Inst. Meeresforsch Bremerhaven 4, 153-170.

Gillbricht, M., 1959. Die Planktonverteilung in der Irminger See im Juni 1955. - Ber. dt. wiss. Kommn Meeresforsch. 15, 260-275.

Gillbricht, M., 1969. Calculations in marine planktology. Practical and theoretical problems. - Int. Revue ges. Hydrobiol. 54, 645-660.

Gillbricht, M., 1974. Ein Problem bei der Berechnung von Regressionsgeraden. - Ber. dt. wiss. Kommn Meeresforsch. 23, 120-129.

Gillbricht, M., 1977. Phytoplankton distribution in the upwelling area off NW Africa. - Helgoländer wiss. Meeresunters. 29, 417-438.

Gillbricht, M, 1983. Eine "red tide" in der südlichen Nordsee und ihre Beziehungen zur Umwelt. Helgoländer Meeresunters. 36, 393-426. 
Goedecke, E., 1956. Über das Verhalten des Oberflächensalzgehaltes in der Deutschen Bucht während der Jahre 1873-1944 in Verbindung mit langjährigen Salzgehaltsreihen der südlichen Nordsee. - Ber. dt. wiss. Kommn Meeresforsch. 14, 109-146.

Goering, J. J., Nelson, D. M. \& Carter, J. A., 1973. Silicid uptake by natural populations of marine phytoplankton. - Deep Sea Res. 20, 777-789.

Grasshoff, K., 1976. Methods of seawater analysis. Verl. Chemie, Weinheim, $317 \mathrm{pp}$.

Grill, E. V. \& Richards, F. A., 1964. Nutrient regeneration from phytoplankton decomposing in sea water. - J. mar. Res. 22, 51-69.

Hagmeier, E., 1961. Plankton-Äquivalente. - Kieler Meeresforsch. 17, 32-47.

Hart, T. J., 1934. On the phytoplankton of the South-West Atlantic and the Bellinghausen Sea, 1929-31. - Discovery Rep. 8, 1-268.

Hart, T. J., 1942. Phytoplankton periodicity in Antarctic surface waters. - Discovery Rep. 21, 261-356.

Hensen, V., 1887. Über die Bestimmung des Plankton's oder des im Meere treibenden Materials an Pflanzen und Thieren. - Ber. Kommn wiss. Unters. dt. Meere 5, 1-107.

Hoffmann, C., 1956. Untersuchungen über die Remineralisation des Phosphors im Plankton. - Kieler Meeresforsch. 12, 25-36.

Johnston, R. \& Jones, P. G. W., 1965. Inorganic nutrients in the North Sea. - Ser. Atlas mar. Environ. $11,1-3$.

Juday, C. \& Birge, E. A., 1931. A second report on the phosphorus content of Wisconsin lake waters. - Trans. Wis. Acad. Sci. Arts Lett. 26, 353-382.

Jørgensen, E. G., 1955a. Variations in silica content of diatoms, - Physiologia Pl. 8, 840-845.

Jørgensen, E. G., 1955b. Solubility of silica in diatoms. - Physiologia Pl. 8, 846-851.

Kalle, K., 1937. Nährstoff-Untersuchungen als hydrographisches Hilfsmittel zur Unterscheidung von Wasserkörpern. - Annln Hydrogr. Berlin 65, 1-18.

Kalle, K., 1953. Der Einfluß des englischen Küstenwassers auf den Chernismus der Wasserkörper in der südlichen Nordsee - Ber. dt. wiss. Kommn Meeresforsch. 13, 130-135.

Ketchum, B. H., 1947. The biochemical relations between marine organisms and their environment. - Ecol. Monogr. 17, 309-315.

Krey, J., 1953. Plankton- und Sestonuntersuchungen in der südwestlichen Nordsee auf der Fahrt der „Gauss” Februar/März 1952. - Ber. dt. wiss. Kommn Meeresforsch. 13, 136-153.

Lewin, J. C., 1961. The dissolution of silica from diatom walls. - Geochim. Cosmochim. Acta 21, 182-198.

Nansen, F., 1902. On hydrometers and the surface tension of liquids. - Scient. Results Norw. N. polar Exped. $3(10), 1-87$.

Nathanson, A., 1906. Über die Bedeutung vertikaler Wasserbewegungen für die Produktion des Planktons im Meere. - Abh. sächs. Akad. Wiss. (Math.-phys. Kl.) 5, 359-441.

Nordli, E., 1957. Experimental studies on the ecology of Ceratia. - Oikos 8, 200-265.

Paasche, E., 1973. Silicon and the ecology of marine plankton diatoms. II. Silicate-uptake kinetics in five diatom species. - Mar. Biol. 19, 262-269.

Postma, H., 1966. The cycle of nitrogen in the Wadden sea and adjacent areas. - Neth. J. Sea. Res. 3, 186-221.

Postma, H., 1973. Transport and budget of organic matter in the North Sea. - In: North Sea science. Ed. by E. D. Goldberg. The MIT Press, Cambridge, Mass., 326-334.

Postma, H. \& Kalle, K., 1955. Die Entstehung von Trübungszonen im Unterlauf der Flüsse, speziell im Hinblick auf die Verhältnisse in der Unterelbe. - Dt. hydrogr. Z. 8, 137-144.

Raben, E., 1914. Vierte Mitteilung über quantitative Bestimmungen von Stickstoffverbindungen im Meerwasser und Boden, sowie von gelöster Kieselsäure im Meerwasser. - Wiss. Meeresunters. (Abt. Kiel) 16, 207-229.

Redfield, A. C., Ketchum, B. H. \& Richards, F. A., 1963. The influence of organisms on the composition of sea water. - In: The sea. Ed. by M. N. Hill. Wiley, New York, 2, 26-77.

Richards, F. A., 1958. Dissolved silicate and related properties of some western North Atlantic and Caribbean waters. - J. mar. Res. 17, 449-465.

Sakshaug, E., Andresen, K., Myklestad, S. \& Olsen, Y., 1983. Nutrient status of phytoplankton communities in Norwegian waters (marine, brackish, and fresh) as revealed by their chemical composition, - J. Plankt. Res. 5, 175-196. 
Sakshaug, E. \& Olsen, Y., 1986. Nutrient status of phytoplankton blooms in Norwegian waters and algal strategies for nutrient competition. - Can. J. Fish. aquat. Sci. 43, 389-396.

Schell, D. M., 1974. Uptake and regeneration of free amino acids in marine waters of Southeast Alaska. - Limnol. Oceanogr. 19, 260-270.

Schöne, H., 1977. Die Vermehrungsrate mariner Planktondiatomeen als Parameter in der Ökosystemanalyse. Habil. Schr., RWTH Aachen, 323 pp.

Schreiber, E., 1927. Die Reinkultur von marinem Phytoplankton und deren Bedeutung für die Erforschung der Produktionsfähigkeit des Meerwassers. - Wiss. Meeresunters. (Abt. Helgoland) $16(10), 1-34$.

Steele, J. H., 1958. Production studies in the Northern North Sea. - Rapp. P.-v. Réun. Cons. int. Explor. Mer. 144, 79-84.

Steemann Nielsen, E. \& Hansen, V. K., 1959. Measurement with the carbon-14 technique of the respiration rates in natural populations of phytoplankton. - Deep Sea Res. 5, 222-233.

Steiner, M., 1938. Zur Kenntnis des Phosphatkreislaufs in Seen. - Naturwissenschaften 26, 723-724.

Steuer, A., 1910. Planktonkunde. Teubner, Leipzig, 723 pp.

Stewart, A. J. \& Wetzel, R. G., 1982. Phytoplankton contribution to alkaline phosphatase activity. Arch. Hydrobiol. 93, 265-271.

Taft, J. L., Taylor, W. R. \& McCarthy, J. J., 1975. Uptake and release of phosphorus by phytoplankton in the Chesapeake Bay estuary, USA. - Mar. Biol. 33, 21-32.

Tarapchak, S. J. \& Nalewajko, C., 1986. Introduction: Phosphorus-Plankton Dynamics Symposium. Can. J. Fish. aquat. Sci. 43, 293-301.

Thomas, W. H., Dodson, A. N. \& Reid, F. M. H., 1978. Diatom productivity compared to other algae in natural marine phytoplankton assemblages. - J. Phycol. 14, 250-253.

Verlencar, X. N., 1985. Urea as nitrogen source for phytoplankton production in coastal waters of Goa. - Indian J. mar. Sci. 14, 93-97.

Weichart, G., 1986. Nutrients in the German Bight, a trend analysis. - Dt. hydrogr. Z. 39, 197-206.

Williams, P. J. le B., 1975. Biological and chemical aspects of dissolved and organic material in sea water, - In: Chemical oceanography. Ed. by J. P. Riley \& U. G. Skirrow. Acad. Press, London, 2, 301-357.

Zeitzschel, B. 1980. Sediment-water interactions in nutrient dynamics. - In: Marine benthic dynamics. Ed. by K. R. Tenore \& B. C. Coull. Univ, of South Carolina Press, Columbia, 195-218. (The Belle W. Baruch Library in Marine Science. 11.) 